\title{
The United States Geological Survey
}

\section{Water Resources Program in Oregon}

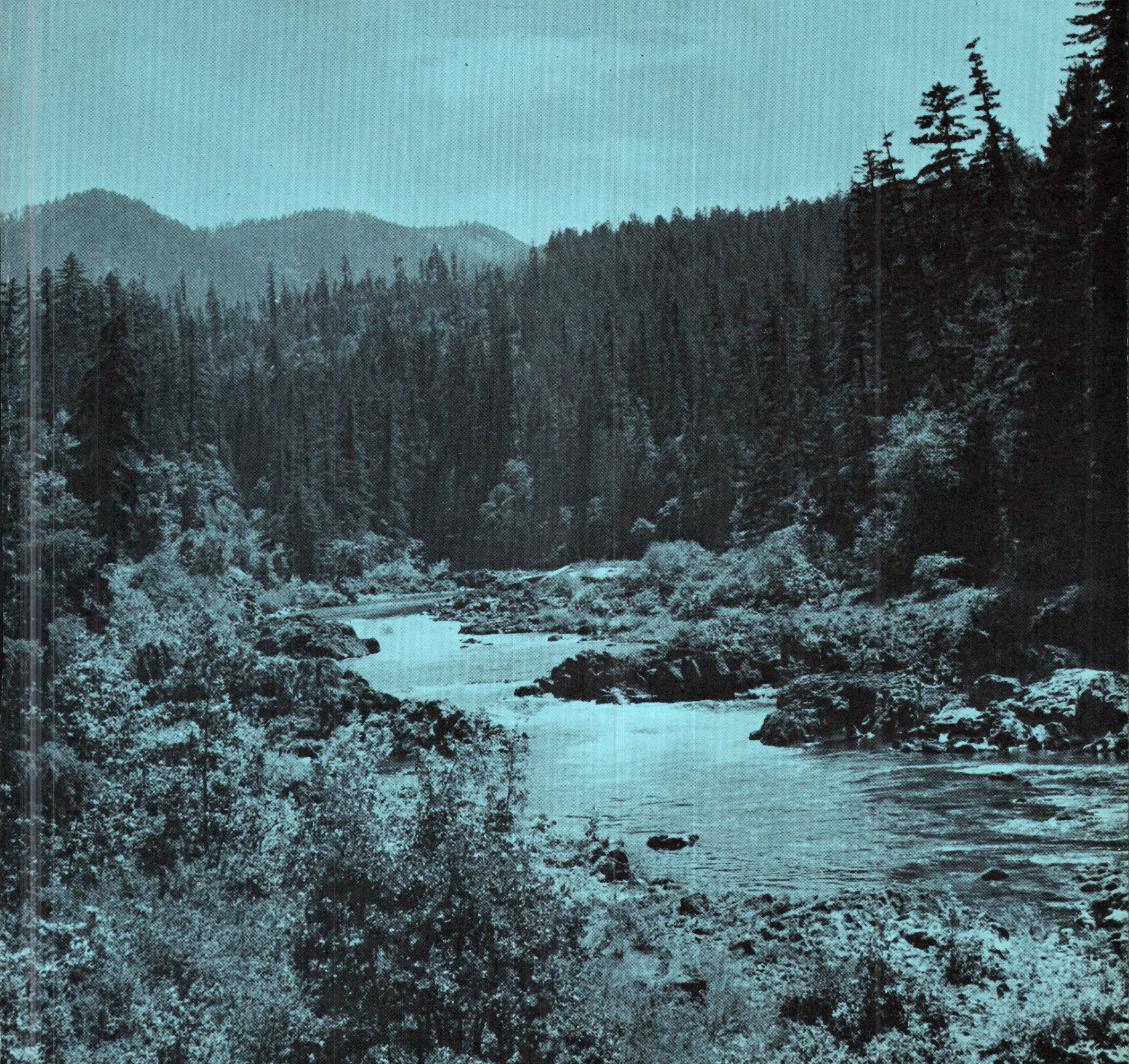




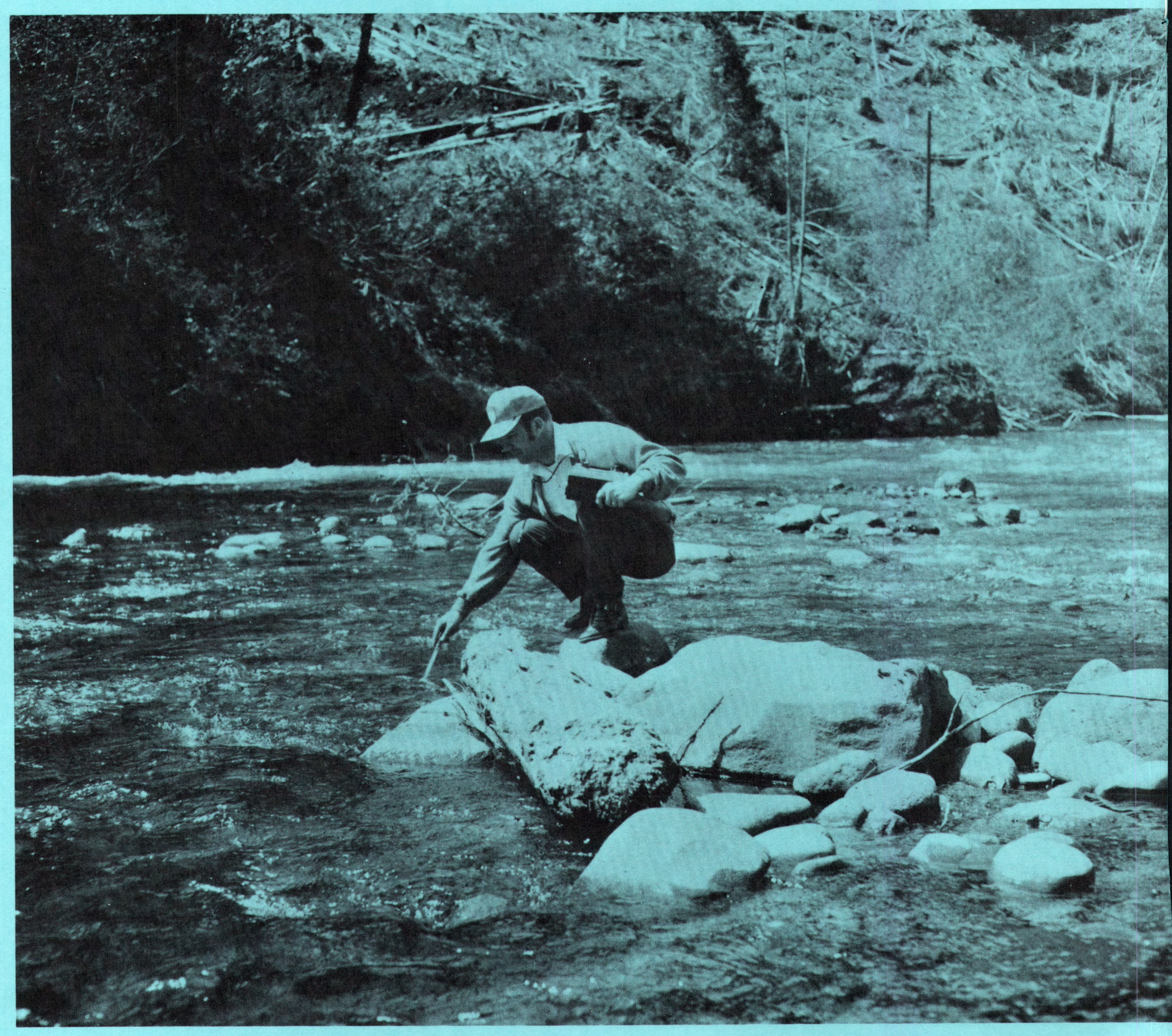




\title{
The United States Geological Survey 1980 Water Resources Program in Oregon
}

\author{
Portland, Oregon \\ March, 1981
}





\section{TABLE OF CONTENTS}

The United States Geological Survey - the Federal Earth-Resources

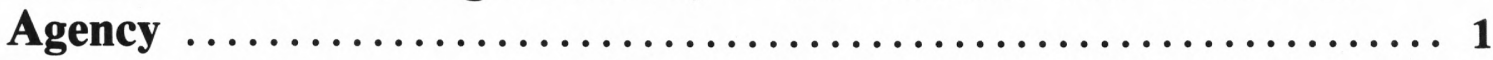

Water Resources Division.............................. 2

National Mapping Division $\ldots \ldots \ldots \ldots \ldots \ldots \ldots \ldots \ldots \ldots \ldots \ldots, \ldots$

Geologic Division .................................... 2

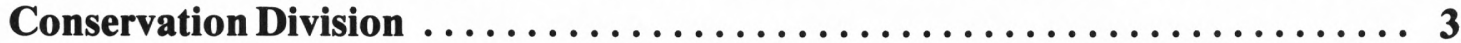

Office of Earth Sciences Application $\ldots \ldots \ldots \ldots \ldots \ldots \ldots \ldots \ldots \ldots, \ldots$

The Water Resources Division Provides Water Facts for the Nation ...... 4

What Does the Oregon District Do? ..................... 6

Hydrologic Data Section Collects Water Data for All Needs .......... 8

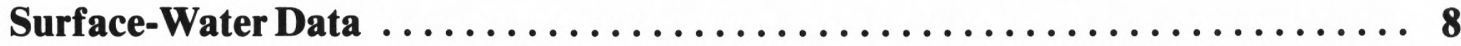

Quality-of-Water Data ............................... 9

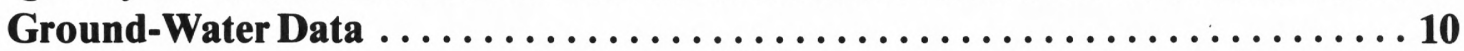

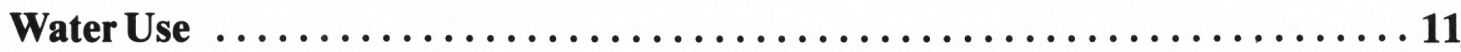

Areal Studies, Modeling, and Special Projects - Work of the

Hydrologic Investigations Section $\ldots \ldots \ldots \ldots \ldots \ldots \ldots \ldots \ldots \ldots \ldots \ldots \ldots$

Statewide Ground-Water Program $\ldots \ldots \ldots \ldots \ldots \ldots \ldots \ldots \ldots \ldots \ldots \ldots \ldots$

Project Summaries ................................. 14

Other Hydrologic Work by the District is Varied $\ldots \ldots \ldots \ldots \ldots \ldots \ldots 23$

Reports are our Most Important Products $\ldots \ldots \ldots \ldots \ldots \ldots \ldots \ldots \ldots$

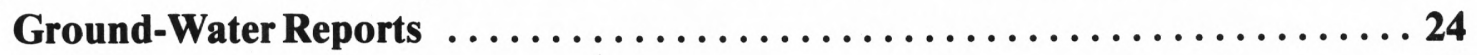

Lake Reports . . . . . . . . . . . . . . . . . . . . . . . . . . . 25

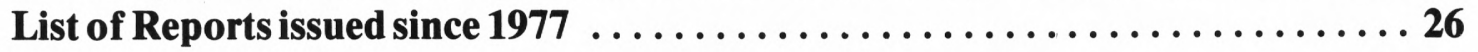



The Geological Survey is a Department of the Interior agency that provides for the people of the United States:

- Accurate maps which show the slope of the land surface, the locations of natural and manmade features, and present land use.

- Information on the composition, structure, and areal occurrence of rocks that is useful in prospecting for minerals and fuels, designing engineering and construction works, and identifying natural hazards such as earthquakes, landslides, and volcanic eruptions.

- Data on surface and ground water essential to the use and conservation of water supplies, the determination of water quality, and the reduction of damage from floods.

- Information on natural processes important in avoiding natural hazards, in maintaining environmental quality, and achieving a harmonious balance with nature.

- Appraisals of the Nation's potential energy and mineral resources to aid resource policymakers and to identify targets for exploration and technologic research.

- Classification of the Federal lands for mineral and waterpower potential and inventories of Federally owned mineral resources.

- Supervision of oil, gas, and mineral lease operations on Federal and Indian lands and on the Outer Continental Shelf to assure resource and environmental conservation and fair return of revenues to the public.

- Maps and reports that make available the results of these activities. 


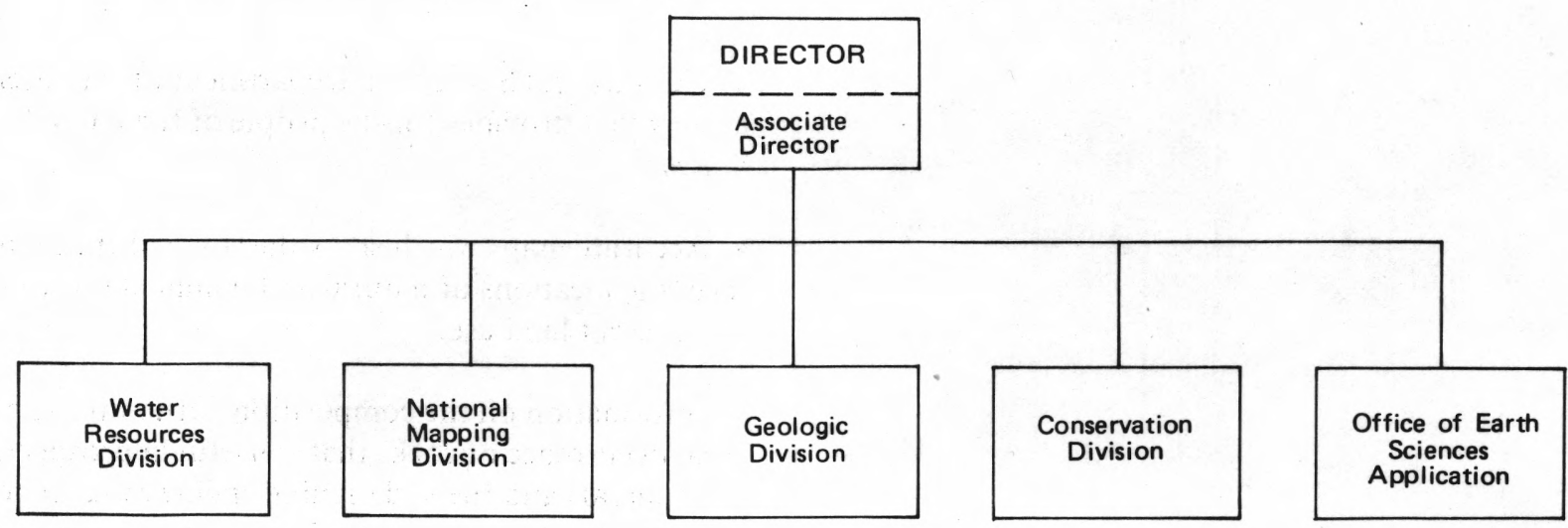

Simplified Organizational Chart for the Geological Survey.

\section{Water Resources Division}

The Water Resources Division investigates and reports on the occurrence, quantity, quality, distribution, and movement of surface and underground water. Work of the Division is described in detail later in this report.

\section{National Mapping Division}

A major responsibility of the Geological Survey is the preparation of maps, charts, and bulletins to delineate the physical features of land areas in the United States and its outlying areas. The main task of the Mapping Division is the preparation of quadrangle maps showing in detail the location, size, and shape of the natural and manmade features of the Earth's surface. Nearly 90 percent of Oregon is covered by maps at either $1: 24,000$ or $1: 62,500$ scale, and by 1989 the entire State will be covered by $1: 24,000$-scale maps.

The new 1:100,000-scale maps fill the gap between the $1: 24,000$ and 1:250,000 scales. Maps at 1:100,000 are in preparation for the entire State and several have been published. The Division assigned a resident cartographer to Oregon in 1980 to coordinate State, Federal, and local mapping.

The Survey's Geography Program includes research and development of techniques for digital mapping and use of satellite imagery. The preparation of land-use and land-cover maps, which are available for about one-third of Oregon, also is under this program.

\section{Geologic Division}

The Geologic Division studies include geologic and geophysical mapping of the areal extent, composition, and structure of rocks at and beneath the surface; research into geologic principles and processes, including specialized research in geochemistry, geophysics, and paleontology; development of information on and exploration for minerals and mineral fuels resources, and land-resource surveys.

Geologic maps have been produced for the entire State at a scale of 1:500,000. More than $44,000 \mathrm{mi}^{2}$ east of the Cascades have been mapped at 1:250,000, and numerous areas at larger scales. In addition, special reports have been prepared on geologic and mineral resources of Oregon wilderness areas.

Geologic-hazards activities include the Earthquake and Volcano Hazards Programs under which the Survey identifies and evaluates potentially hazardous areas. The systematic collection of data, such as seismic records, gaseous emissions, and rates of crustal uplift, make timely warnings possible, if they become necessary. Detailed surveillance of Mount St. Helens began in March 1980 as part of the volcano hazards program and provided information used by local safety officials in issuing warnings for subsequent eruptions, mudflows, and ash falls. These activities are being extended to cover other potentially active Cascade volcanoes. 


\section{Conservation Division}

The Conservation Division classifies Federal lands as to their mineral character and waterpower and waterstorage values; supervises technical operations under geothermal, oil and gas, and other mineral leases on Federal, Outer Continental Shelf, Indian, and petroleum reserve lands. The Division determines the amount of Federally-owned coal, oil shale, or other fuel minerals, before these minerals are offered for lease and development.

The Conservation Division has a Waterpower Classification Branch office and a District Mining Supervisor in Portland.

\section{Office of Earth Sciences Application}

The ESA office programs are directly concerned with applying earth-sciences information to earth-resources management, including (1) application of natural science information in major urban areas to support land-resources decision making; (2) preparation of environmental-impact statements related to the leasing of OCS and Federally owned minerals for exploration and development; and (3) collecting and interpreting remotely sensed data, and applying other aspects of space technology in support of land-resources analysis. Numerous maps and reports have been prepared and released on several aspects of geology, hydrology, and physiography as they relate to land-resource use in the Puget Sound area.

Through the Coordinator for coastal-zone activities, ESA provides information and assistance to the Office of Coastal Zone Management and to other agencies involved in coastal-zone issues. A recent product is the publication on Survey programs in the coastal zone.

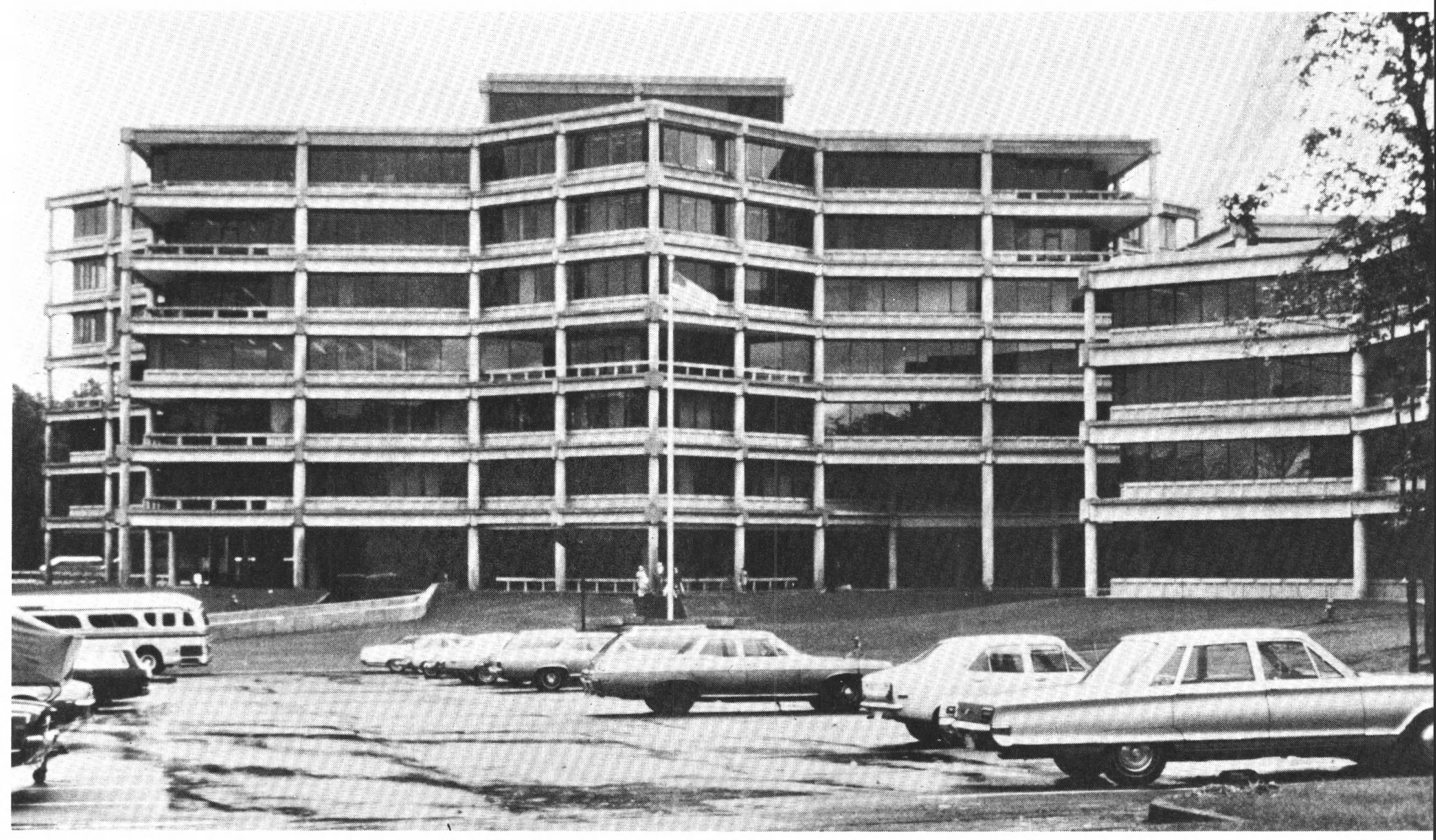




\section{The Water Resources Division Provides Water Facts for the Nation}

The mission of the Water Resources Division, which supports the overall mission of the U.S. Department of the Interior and the Geological Survey, is to provide the hydrologic information and understanding needed for the best use and management of the Nation's water resources for the benefit of the people of the United States.

Headquarters for the Division are at the National Center in Reston, Va. Field activities are dispersed nationwide, with four regional centers and District offices in most States. The chart shows headquarters organization, and the map the locations of Regional and District offices.
To accomplish its mission the Water Resources Division in cooperation with State and local governments and other Federal agencies:

- Collects, on a systematic basis, data needed for the continuing determination and evaluation of the quantity, quality, and use of the Nation's water resources.

- Makes analytical and interpretive water-resource appraisals to describe the occurrence, availability, and physical, chemical, and biological characteristics of surface and ground water.

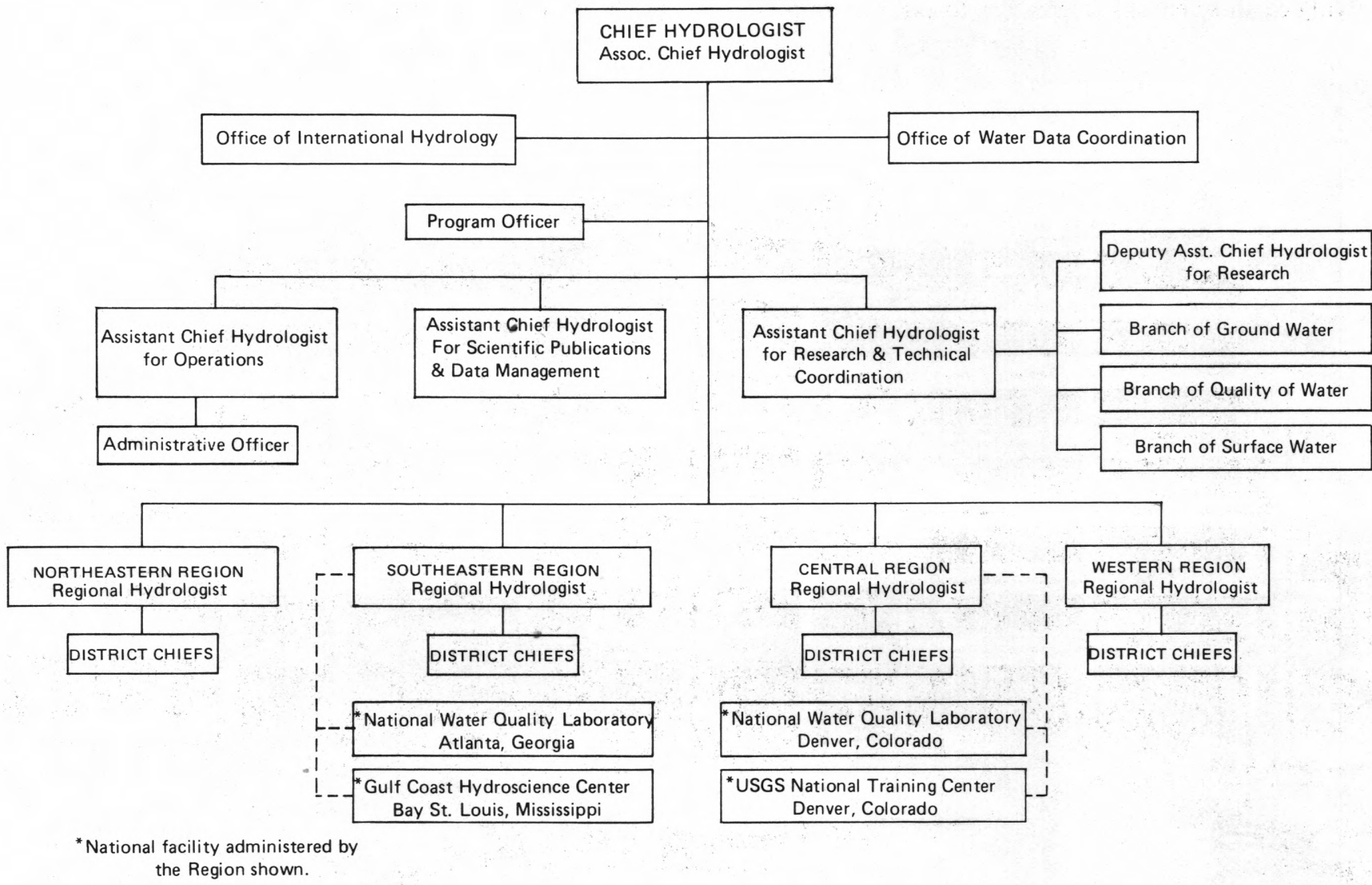

Organizational Chart of the Water Resources Division 
- Does basic and problem-oriented research in hydraulics, hydrology, and related fields of science and engineering to improve investigations and measurement techniques and to understand hydrologic systems sufficiently well to predict quantitatively their response to stress, either natural or manmade.

- Disseminates water data and the results of investigations and research through reports, maps, computerized information services, and other forms of public releases.

- Coordinates the activities of Federal agencies in the acquisition of water data for streams, lakes, reservoirs, estuaries, and ground waters.

- Provides scientific and technical assistance in hy- drologic fields to other Federal, State, and local agencies, to licensees of the Federal Energy Regulatory Commission, and to international agencies on behalf of the U.S. Department of State.

Authority for carrying out this mission derives from legislation of 1879 , which created the Geological Survey; legislation of 1888 and 1894, which provided for gaging the streams and determining the water supply of the Nation; and Congressional appropriations, which have been made annually since 1894. In 1964 the Division's mission was broadened to include the role of lead agency in the coordination of the activities of all Federal agencies in the acquisition of certain water data; this responsibility was assigned to the Department of the Interior by the Office of Management and Budget Circular A-67.

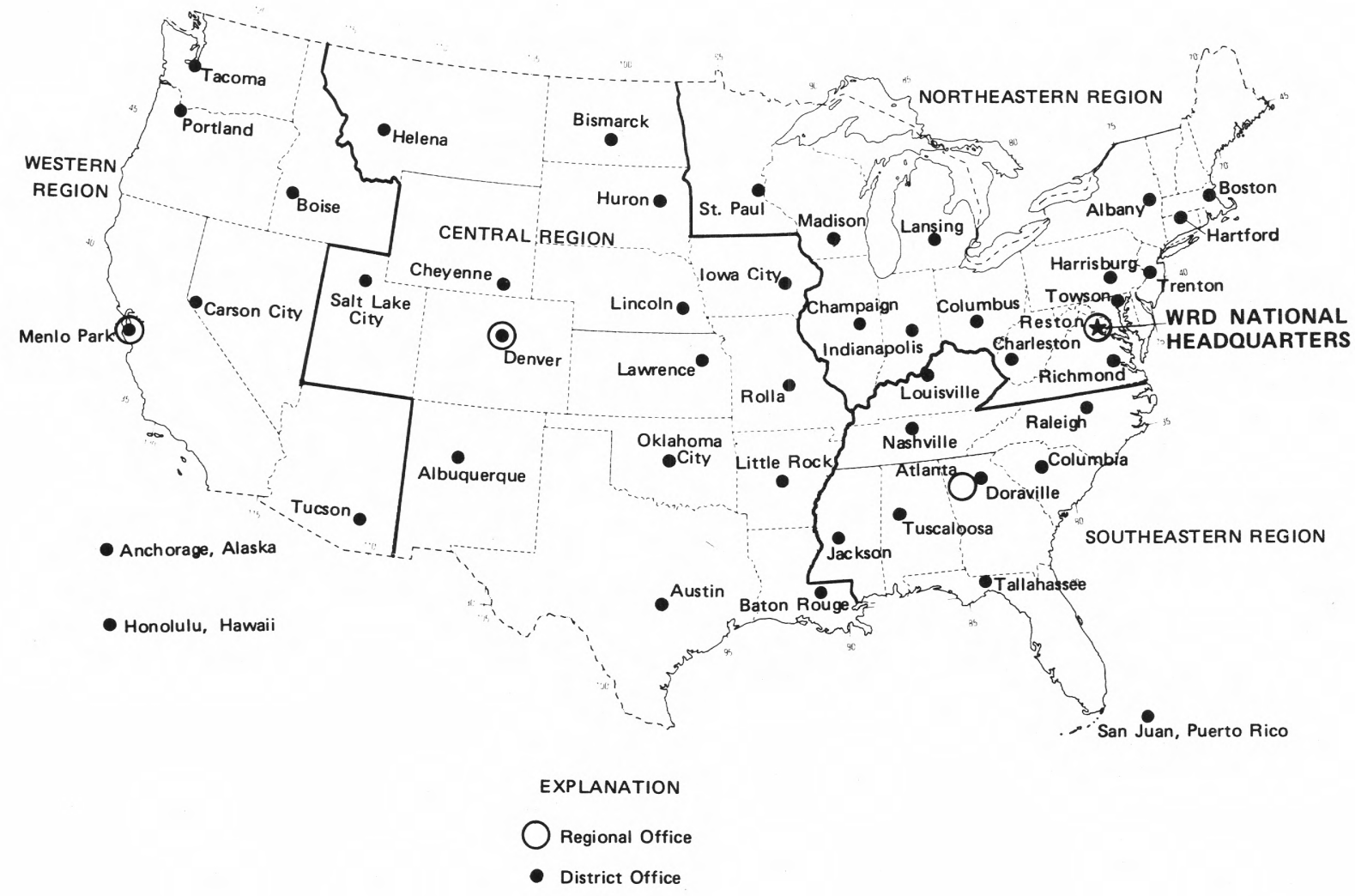

Location of Principal Water Resources Division Offices. 


\section{What Does the Oregon District Do?}

In Oregon, the Survey's water-resources mission is carried out by a staff of about 60 professional, technical, and support people at four field offices and a District office in Portland. As shown by the chart, work is grouped in two sections-Hydrologic Data and Hydrologic Investigations. A list of key personnel, from whom data may be obtained is given inside the back cover.
Oregon Department of Land Conservation and Development

City, County, or Local Agency

City of McMinnville

City of Portland

City of Salem

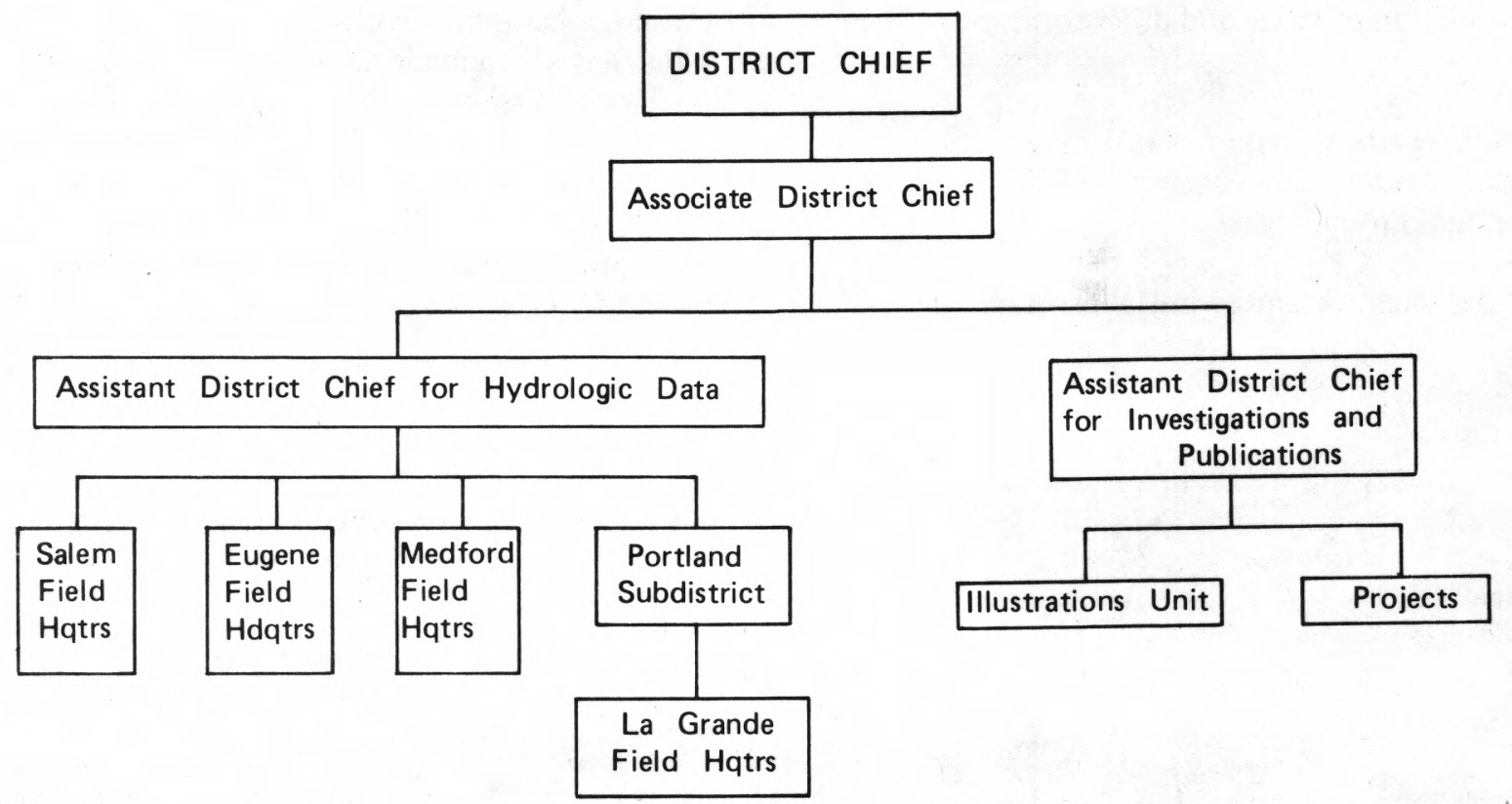

Oregon District Organizational Chart.

Most of Oregon work is under cooperative programs-that is, arrangements and agreements whereby cost of the work, and sometimes part of the effort, are shared jointly by the Survey and another agency. The principal cooperative program is with the Oregon Water Resources Department-a partnership that has continued since 1905. The Survey has cooperative programs with:

\section{State}

Oregon Water Resources Department Oregon Department of Fish and Wildlife Oregon State Highway Commission

\author{
Coos County \\ Douglas County \\ Hood River County \\ Lane County \\ Multnomah County \\ Wasco County \\ Clark County (Wash.) \\ Confederated Tribes of Umatilla Indian Reservation \\ of Oregon \\ Confederated Tribes of Warm Springs Indian \\ Reservation of Oregon \\ Burnt River Irrigation District \\ Coos Bay-North Bend Water Board \\ Eugene Water \& Electric Board \\ Lane Council of Governments
}


Federal agencies that provide financial support for specific stations or parts of the Oregon program include:

Bonneville Power Administration

Bureau of Land Management

Corps of Engineers

Department of Housing and Urban Development

Environmental Protection Agency

Fish and Wildlife Service

Forest Service

National Park Service

National Marine Fisheries Service

Soil Conservation Service

Water and Power Resources Service

In addition, financial support for certain hydrologic data work is provided by the following Federal Energy Regulatory Commission licensees:

Eugene Water \& Electric Board

Idaho Power Company

Pacific Power \& Light Co.

Portland General Electric Co.

Funds for both data collection and project work have increased substantially during the last decade. Total District funds are estimated to be $\$ 2,663,000$ for the 1980 fiscal year and to increase by about 11 percent in 1981 FY. Sources of 1980 funds are shown in the

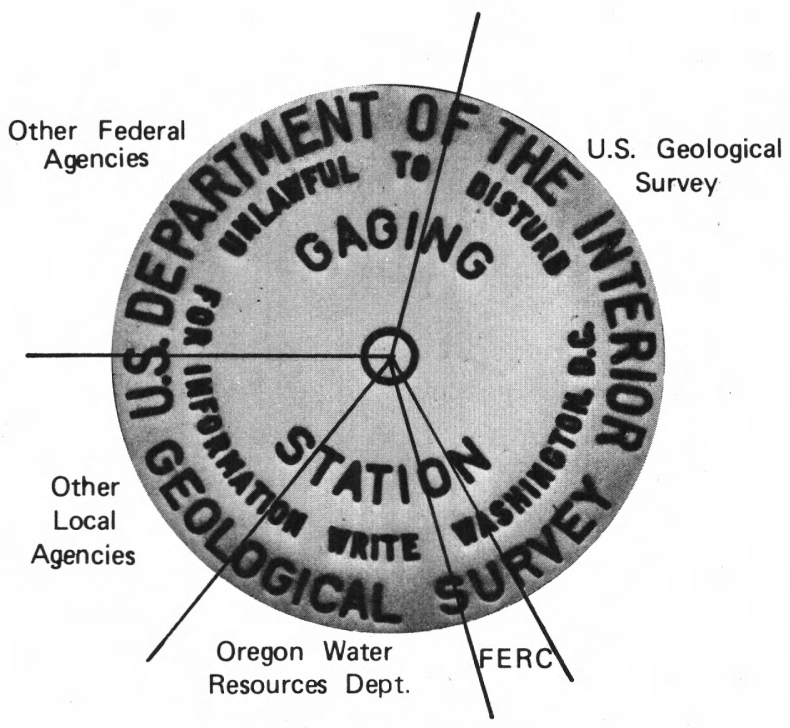

General Sources of District Funds, 1980.
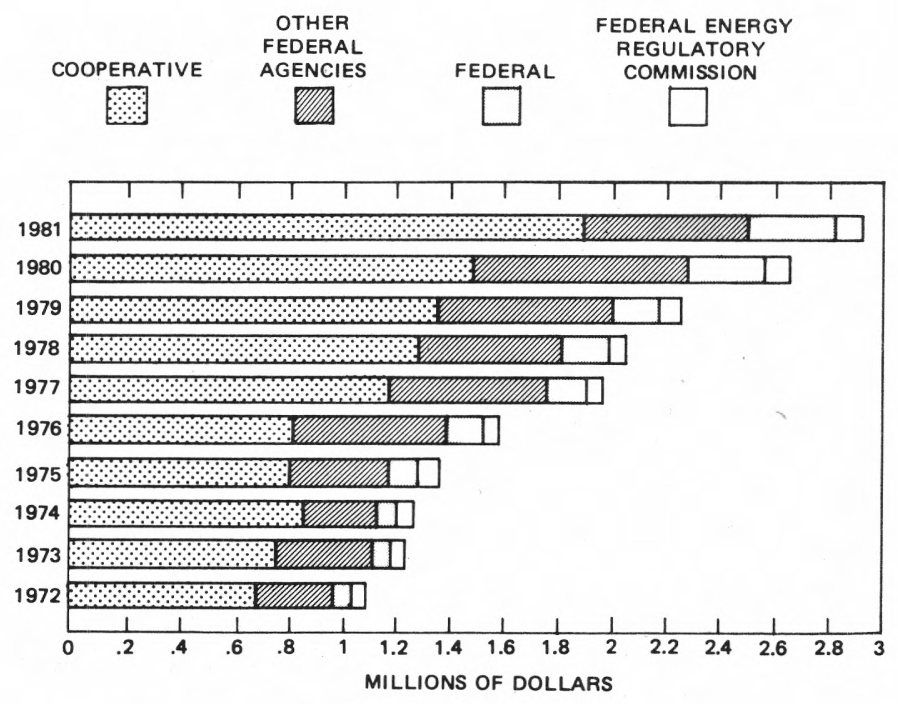

Sources of District Funds, 1972 - 1981.

diagram, and general sources of funds from 1979 to 1981 are given in the graph above.

The number of employees has increased at a far slower rate than funds. Total employees in the District, including part time and WAE, increased only 16 percent from 1970 to 1980 , although available funds increased during that period by 180 percent. During recent years, however, the proportion of professional employees has increased steadily, as shown by the graphs below, primarily because of the increase in the number and complexity of projects.

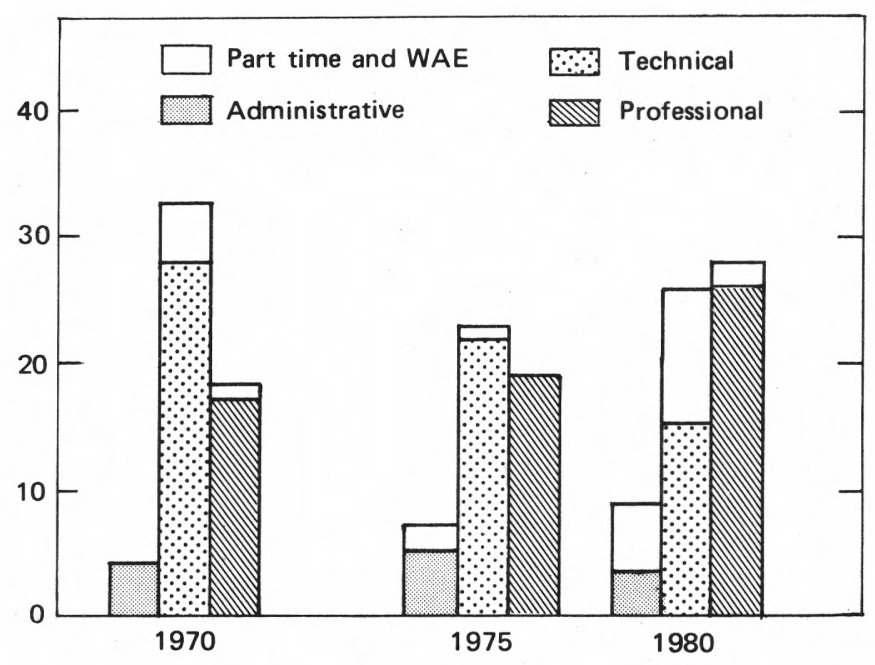

Number of District Employees. 


\section{The Hydrologic Data Section Collects Water Data for All Needs}

This section is responsible for the systematic collection, tabulation, and publication of water data of all types. Most of these data are collected at station operated by the District to provide continuous or periodic measurements of water quantity, quality, or level. Locations of the measurement sites are shown on the following maps. More than 60 percent of district funds go into hydrologic data collection.

Water data are made available to the public through a series of annual reports that include data on streamflows, reservoir and lake levels and contents, stream and lake temperatures, chemical, physical, and biological quality, and ground-water levels.

In addition to the data obtained at regular, long-term stations, hydrologic data of various kinds are collected at specific places for special purposes. Those waterdata activities include the statewide water-use study, water-quality data for studies of dredging effects and fish propagation, flood-insurance studies, and lake inventories. These special activities are described after the discussion of regular hydrologic-data programs. Special reports are generally issued to release data from these studies.

Measuring sites where hydrologic data are being obtained in Oregon in 1980 include:

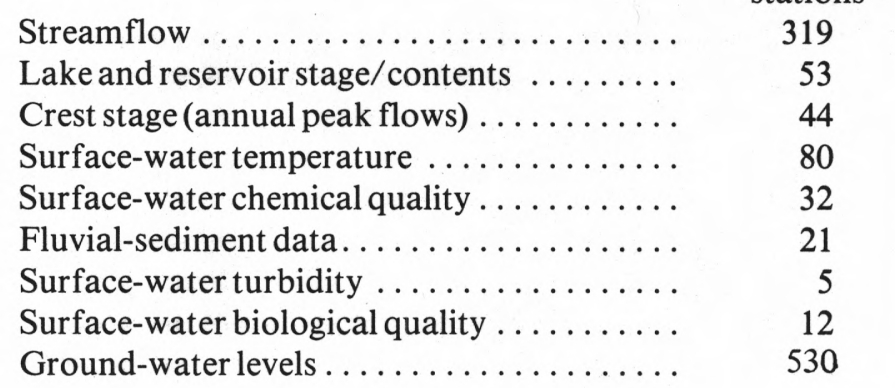

\section{Surface-Water Data}

Continuous records of streamflow and of lake and reservoir levels and outflow (see map) are obtained as part of the National assessment of water resources and to provide information for water management. These data are used in planning, designing, and operating water-supply facilities, in regulating water use and water rights, and for scientific purposes. Statistical data are essential for determining long-term trends in runoff and relating those trends to climate, water use, or changes in land use. These data also are useful in assessing the probability of natural disasters, such as floods and droughts.

A number of stations are operated so as to provide "real-time" flow data to agencies who operate the hydropower and flood-control reservoirs in the Northwest region. Real-time data also are useful in equitable allocation of water among holders of water rights and in planning for supplemental releases from reservoirs for low-flow augmentation or to aid in migration of anadromous fish.

Most streamflow and lake stations are continuousrecord stations equipped with digital-punch recorders for fast machine processing of data. Daily records from these stations are produced by computer, and computer printouts are the basic element of the surface-water data reports.

Streamflows in the Columbia River at The Dalles and in the Willamette River at Portland are obtained using unique Acoustic Velocity Meters (AVM). These instruments use a sound wave, moving diagonally across the river, as an index to stream velocity. The system provides accurate flow measurements in slack water at the head of a reservoir or where streamflow is affected by backwater from another stream or by tidal effects. The AVMs are programmed to compute stream discharge values directly from the velocity-index readings. The discharges are printed out in the AVM shelter and are entered automatically into the Columbia Basin teletype network to make them available to water managers on a real-time basis.

Crest-stage stations are sites where data on annual flood peaks and discharges are obtained (map, p. 9). Most are on small streams with drainage areas less than 15 square miles. Many of the present stations have been in operation for more than 10 years, and flood data are available for more than 100 other stations that have been discontinued because the length of record was judged to be adequate for flood-frequency analysis. Data from the crest-stage program were used with records from long-term continuous stations to prepare the report on "Magnitude and frequency of floods in western Oregon" (OFR 79-553). 


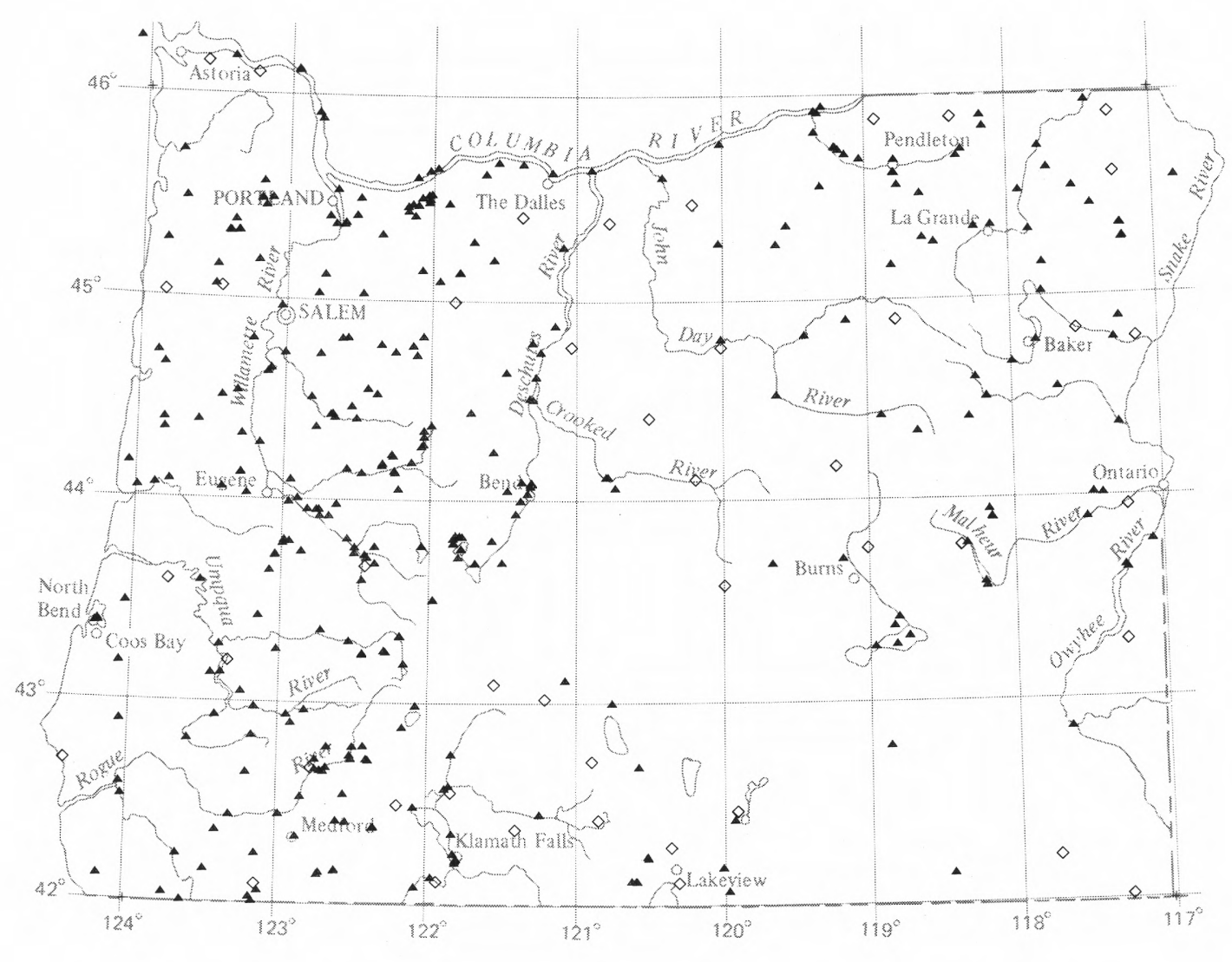

Surface-water stations in Oregon. Triangles show locations of recording stream and reservoir gages; open squares mark crest-stage sites

\section{Quality of Water Data}

Water-quality data are obtained at 90 stations in Oregon to help define and monitor the physical, chemical, and biological character of surface waters. Nearly every use of water, both in stream and off stream, is affected or limited by some aspect of water quality. Water quality is especially important for the principal off-stream uses of municipal, industrial, and irrigation supply and for in-stream uses of fish propagation and migration.

Daily temperature records are obtained at nearly all the water-quality stations. Temperature is of paramount importance for the survival of trout and anadromous fish and also affects the capacity of a stream to assimilate wastes.

The most comprehensive water-quality data are recorded at the 12 NASQAN (National Stream Quality Accounting Network) sites (map, p. 10). NASQAN stations are operated to provide a broad range of quality information for a particular stream basin. Thus, they generally are near the downstream end of the basin, such as the Willamette River station at Portland and the Owyee River station near Vale. Information from the NASQAN sites provides a water-quality "overview" to help assess general quality aspects of the Nation's rivers. Data from the network, for states such as Oregon, provide a general water-quality base against which future quality alterations, or seasonal variations, can be measured. Data obtained at most NASQAN stations include continuous records of temperature and monthly determinations of chemical quality, sediment, biological quality, and turbidity. At some stations, quarterly analysis are made also of trace elements and pesticides.

The District operates a small water-quality laboratory in Portland, although most analysis are made at the Survey's Central Laboratory in Denver. Sediment-size analysis and bacteriological measurements are made in the Portland laboratory which also prepares samples for transmittal to the Central Laboratory. 


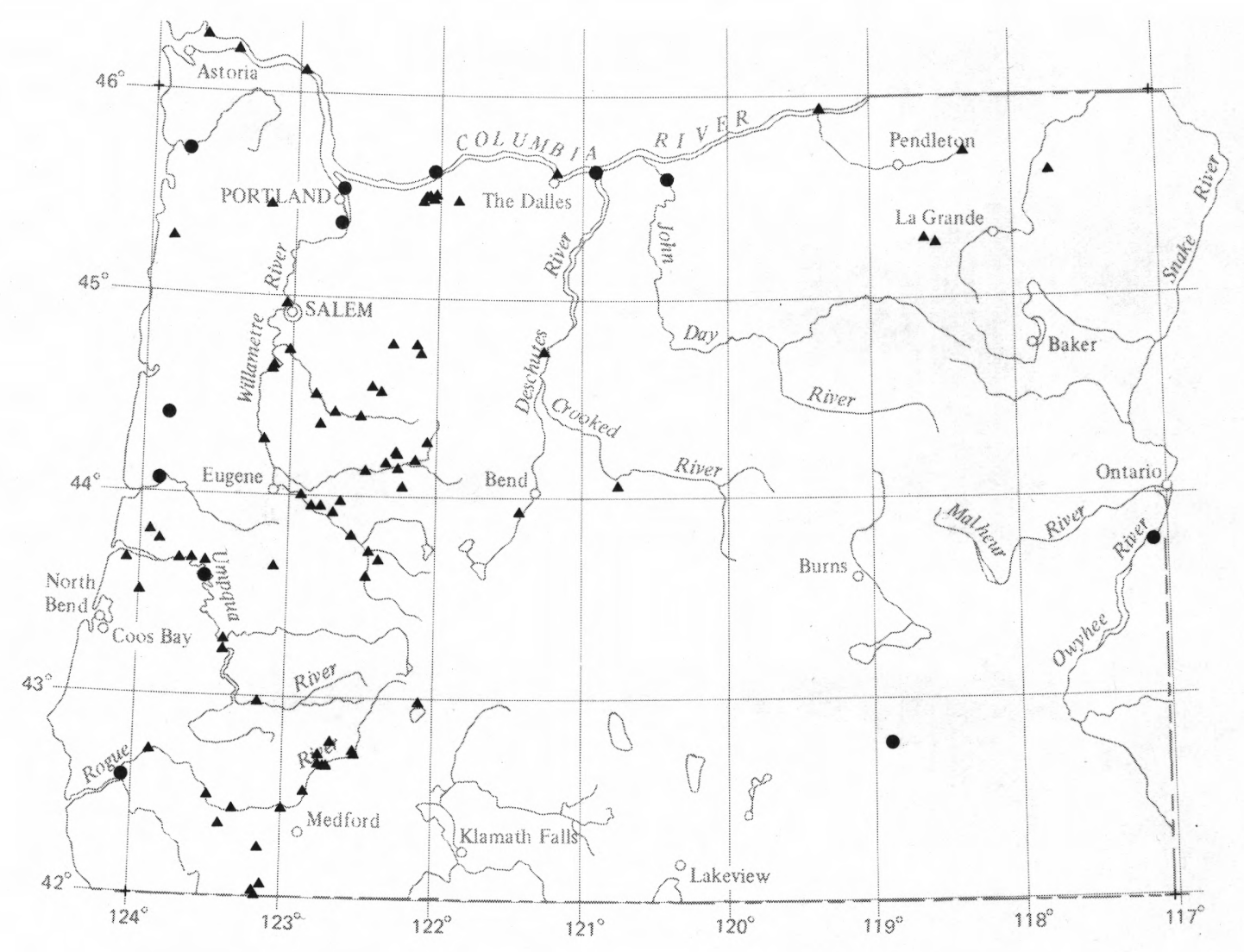

Water-quality stations. Circles denote NASQAN stations.

In addition to the operation of hydrologic waterquality data stations, Oregon has several water-quality projects (Salem urban quality, Bull Run watershed, concentration velocity, etc.). Data on ground-water quality also are obtained as an integral part of every ground-water areal and basin study. Special waterquality data was also obtained as needed in response to special events such as unusual floods or the Mount St. Helens eruptions.

\section{Ground-Water Data}

Ground-water levels are measured periodically in cooperation with the Oregon Water Resources Department, in a statewide network of about 500 wells to monitor the water-level fluctuations in principal aquifers and water-use areas (map, p. 11). Most wells are measured twice each year-once in early spring following the period of winter recharge and again in the fall after the summer period of most intensive water use. A few wells are measured monthly or have automatic recorders to obtain continuous water-level records. Records for about 100 wells are published in the annual Oregon data reports; data for others are on file in the Survey district office and at Oregon Department of Water Resources.

Historical records of water level are useful in determining natural seasonal and long-term fluctuations resulting primarily from climatic effects and the natural movement of water through the hydrologic cycle. Records for some wells cover a 50-year period, so extend over several wet and dry periods. The data also provide a base against which man-induced changes caused by intensive pumping of ground water can be determined. The effects of other alterations of the natural environment, such as reservoir construction, straightening and deepening stream channels, draining wetlands, or extending storm sewers over a large area, also can be documented using water-level data. 


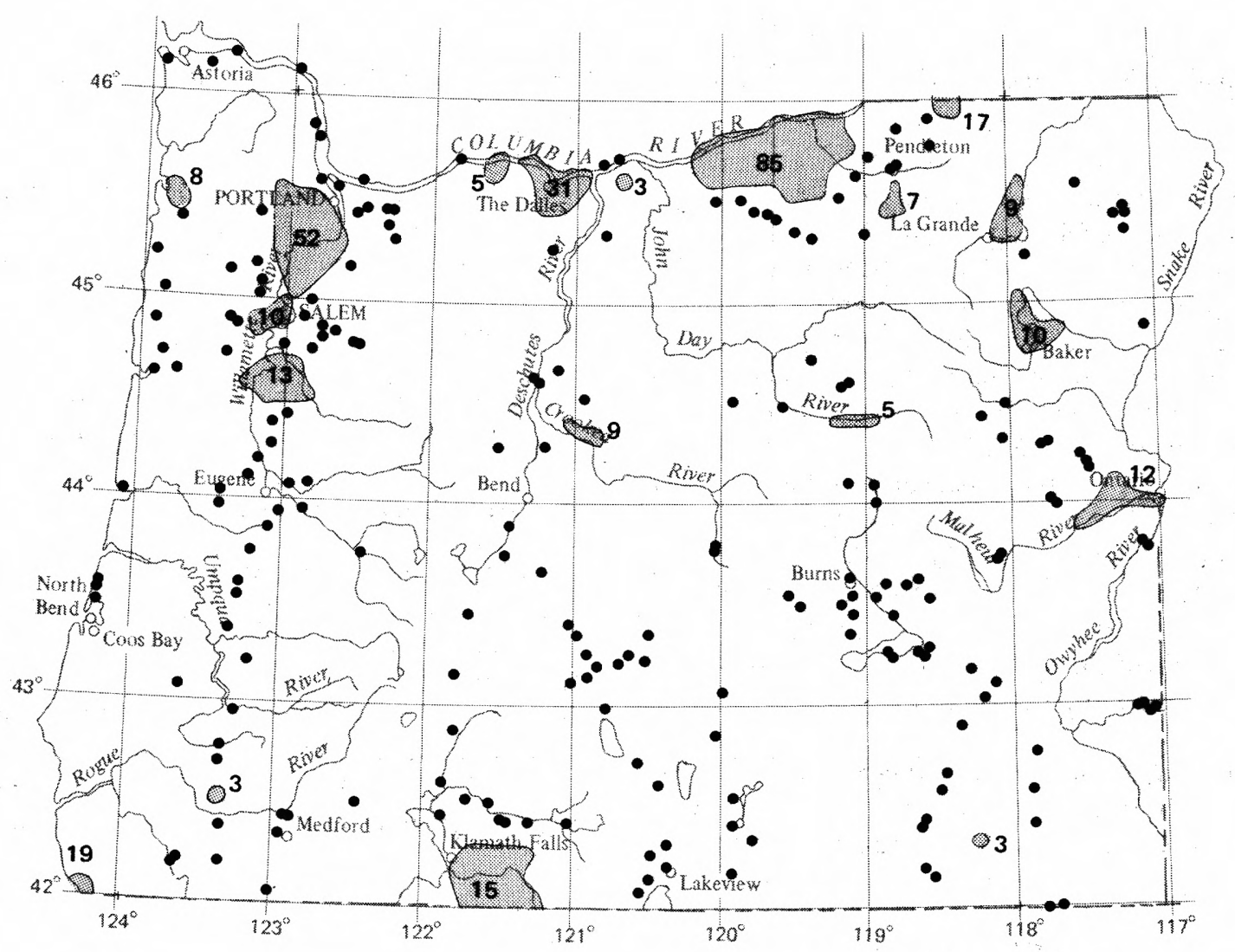

Wells where ground-water levels are measured periodically.

A second part of the ground-water data program is the geophysical logging of water wells to obtain hydrologic and geologic data, primarily in support of areal projects and to obtain data for use in future basin projects. These logs are made by lowering a series of probes on electrical cables into an unused well or one from which the pump has been temporarily removed. Vertical logs are made of resistivity, spontaneous potential, natural gamma radiation, temperature, well diameter, fluid conductivity, and flow of water in the well bore. These data then can be coordinated with other information about the well. Logs are made of about 100 wells annually.

\section{Water Use}

A new cooperative program was started in 1979 to collect systematic water-use data throughout the State. Under this program, the State Water Resources Department is responsible for collecting, processing, and storing records of water use in an automatic data-process- ing (ADP) system. In the past, available data on water use had been fragmentary, inaccurate, and inconsistent from one water-use area or water-use category to another. The organization of those data on a standardized basis will provide accurate, up-to-date data needed by planning and management agencies. The Oregon water-use program will allow these agencies to better coordinate water supplies and water needs planning with current and historical uses of water.

The Water Resources Department is developing methods for monitoring actual water use in the field. Measuring devices will be installed at selected water-use facilities to obtain representative data on various uses. The ADP system will permit extrapolation of those data to provide a statewide tabulation of use by basin, county, or other statistical area. Standardization of these data with Federal use categories will enable the Survey to produce more accurate water-use reports than in the past. 
This section is responsible for the areal and specialsubject projects in the District and for the preparation of all reports except the annual hydrologic-data reports. Projects include urban studies, ground-water areal projects, water-quality studies, ground-water modeling, and special studies such as those concerned with the acoustical-velocity meter and the investigation of settling velocities of particles in water. Each project is concerned with a special problem area, subject, or need for hydrologic analysis. Most projects require several years to complete and include a data-collection phase, an analytical phase, and a report-preparation phase. Each project culminates in one or more reports to make available to the public the data obtained and the interpretations and conclusions made.

Work of the Hydrologic Investigations Section has expanded rapidly in recent years, primarily because of increased ground-water studies. Funds for the section have increased from about 25 percent of the District total in 1973 to about 39 percent in 1980 and more than 44 percent estimated in 1981 ( $\$ 1.3$ million). Fourteen of the professional employees in the District are assigned to the Hydrologic Investigations Section.

The map below shows locations of current areal projects and each project is summarized on following pages.

\section{Statewide Ground-Water Program}

In 1978, the Survey and State Water Resources Department, in response to a request from the Governor of Oregon, began planning a series of reports to appraise the State's ground water on a basin-by-basin basis. The basin designations were the 17 hydrologic basins, many corresponding to major stream basins such as the Umpqua and Malheur River basins, which had been used for previous multiagency studies ( see map, next page).

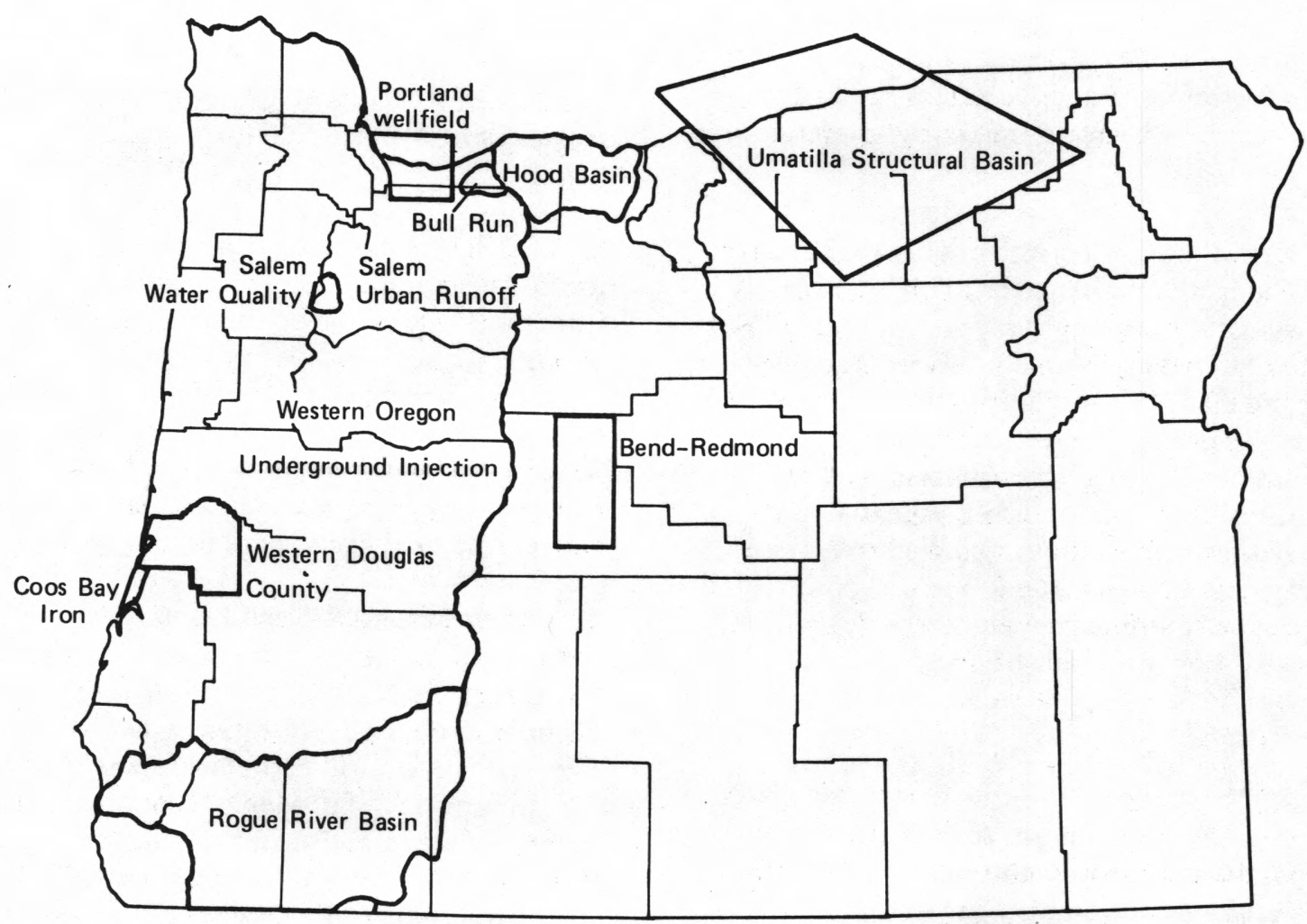

Ongoing areal projects. 
Basin studies for the entire State would be completed in about 12 years. In 1979, the Rogue River basin was selected as the first basin to be studied. The next two will be the Deschutes and John Day basins; scheduling for the other basins will be developed later.

The series of statewide ground-water basin appraisals are designed to evaluate the ground-water resource in each basin. For each aquifer, information is to be developed on the areal extent, thickness, hydrologic properties, and amount and sources of recharge. Detailed maps will be prepared for more than a dozen hydrogeologic properties, such as lithology, saturated thickness, transmissivity, and head distribution. In addition, maps and diagrams will depict water-quality data, variations, and changes.

All the data for all wells in the basin will be stored in a computer ADP system, so that available well information for any site or on any hydrologic property can be retrieved easily and quickly. When fully operational, the ADP system will have data for more than 100,000 wells and 12,000 ground-water rights, with new data added as additional wells are drilled or water-rights applications processed. The complete and detailed appraisals will provide any information needed to select future well sites and to manage ground-water development without excessive draw-downs of water level,

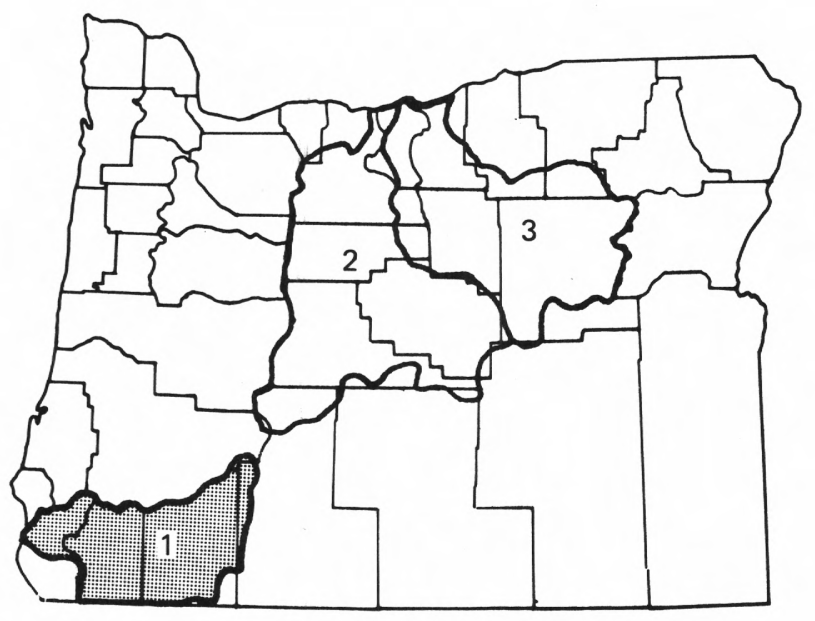

Priorities for statewide ground-water appraisals.

1. Rogue River basin (in progress);

2. Deschutes River basin; 3. John Day basin mutual interference, or other problems that characterize present dẹvelopment in places.

The map shows local areas where ground-water studies are needed. These areas will eventually be covered under the statewide ground-water assessment program, but local studies may be needed sooner for many of them. In each area, systematic ground-water data are lacking and problems are associated with either water use or needs or both. Common problems include domestic water needs in rapidly growing areas such as the Tillamook County coast, Washington County, and Cottage Grove area. Other areas, such as Coquille and Sheridan, have limited ground water available, but need sizable supplies for industry or irrigation. In addition, potential coal development in the Coquille area would require some water and could result in impacts to local water supplies. The Vale area has geothermal resources that could be developed, but use of those resources for space heating or industrial application would require water and could impact water sources. Additional water could be used for irrigation or by industry, if available there. Another problem in the Vale area is the occurrence of arsenic in ground water in excess of EPA drinking water standards. The area affected, depth zone of occurrence, and source of the dissolved arsenic have not been determined.

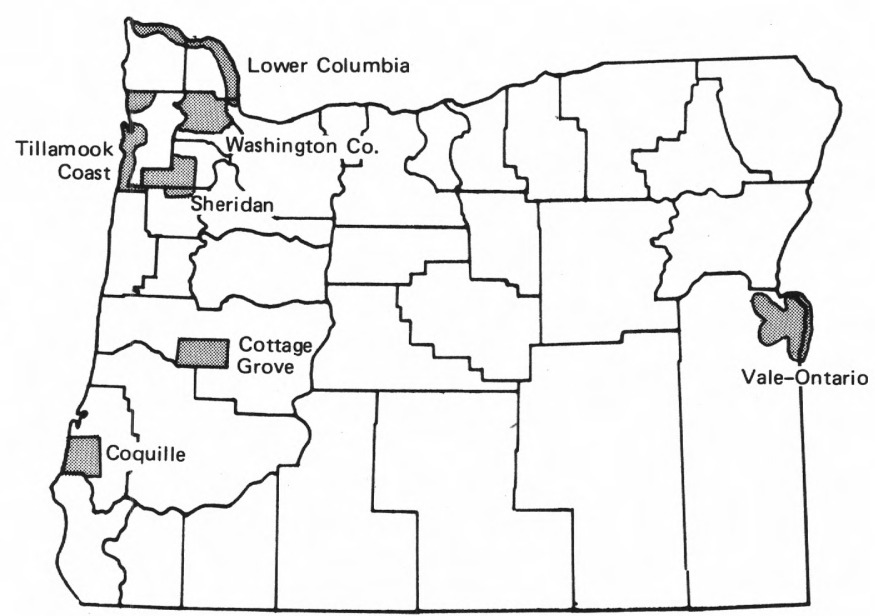

Local areas where ground water studies are needed. 
Project: Flood-profile studies; D. D. Harris, project chief

Cooperators: Department of Housing and Urban Development (HUD) and Douglas County

Project period: $1970-81$

Description: Data on flood elevations and areas are needed to minimize flood losses, to curtail the building of structures in areas subject to flooding, and to administer the HUD flood-insurance program. These data are obtained by detailed photogrammetric and land surveys, and the use of computer-generated flood profiles and discharge values for 500-, 100-, 25-, and 10-year floods.

Objectives: To provide information to HUD and local governments on flood elevations and profiles, mapped boundaries of the 100- and 500-year floods and the 100-year floodway, and flood discharges needed for the flood-insurance program and for flood-plain zoning.

Progress: Flood-profile studies have been completed for 510 stream miles in selected reaches of the Umpqua and Rogue River systems, including studies for the population centers of Drain, Elkton, Myrtle Creek, Riddle, Yoncalla, and Grants Pass. A profile study is currently underway on a selected reach of Calapooya Creek.

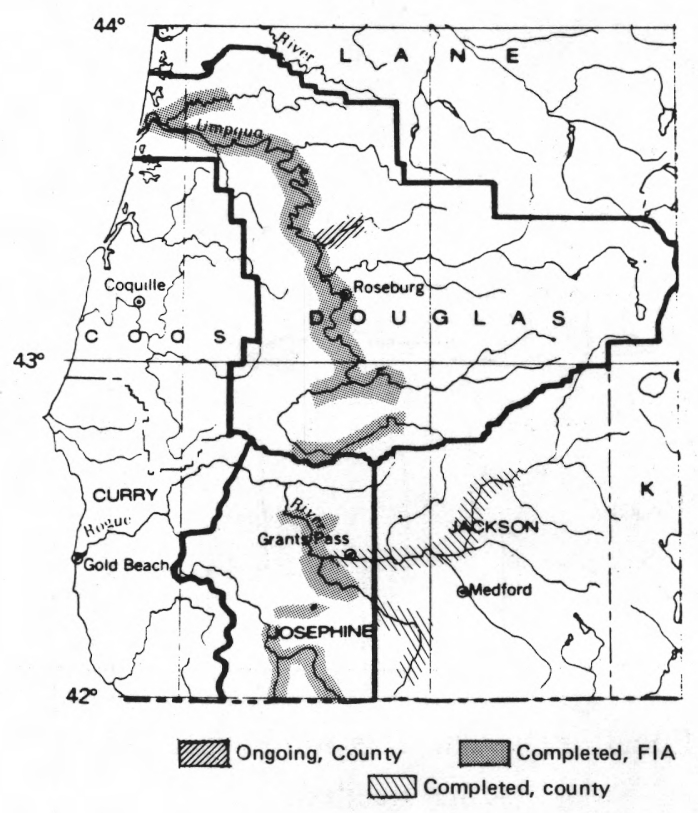

Locations of flood-profile studies.

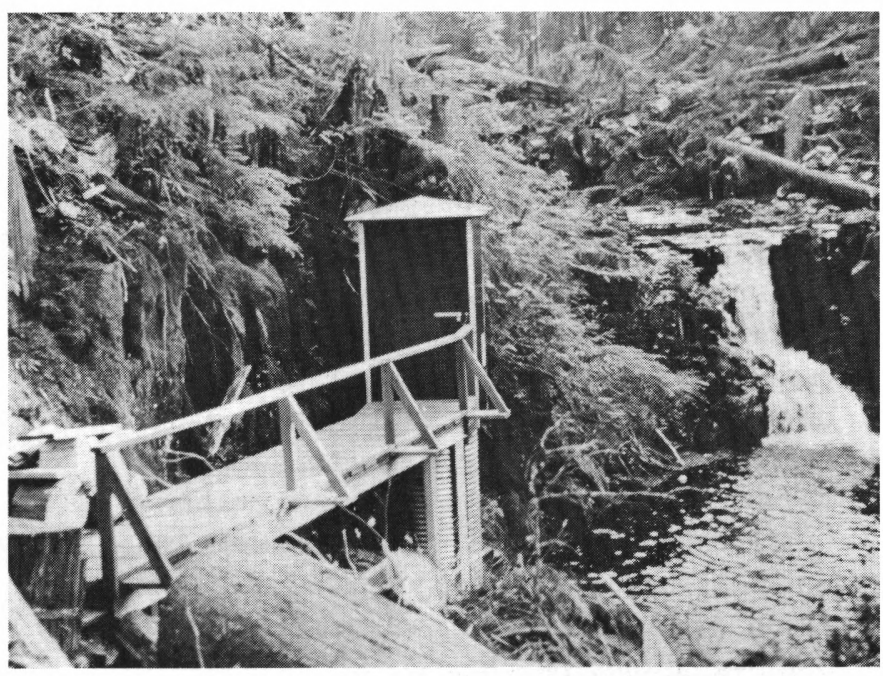

Project: Water quality in Bull Run watershed; Michael V. Shulters, project chief

Cooperator: City of Portland

\section{Project Period: 1977-83}

Description: This 7-year project is related to land use in the 100-square-mile Bull Run watershed, the principal water source for the Portland area. The basin, in Mount Hood National Forest, was established as a water-supply reserve with entry and activities restricted to safeguard the purity and quality of the water.

Objectives: To evaluate any changes in water quality of streams in the Bull Run River basin in order to separate (1) water-quality effects caused by man's activities (primarily logging and road building) from (2) effects resulting from natural causes.

Progress: Water-quality stations, equipped with automatic pumping samplers to obtain daily suspended-sediment and chemical-quality data were established and operated on the North and South Forks and main stem of Bull Run River and on Fir Creek. Continuous records of water temperature and conductivity also are obtained at these stations. Diel data also are being collected at the four sites during low-flow periods each year. Physical, chemical, and bacteriological data are collected periodically at eight other stations on tributary streams. Biological data include coliform, streptococci, and benthic population counts and periphyton-growth data. Data also are being obtained on sediment accumulation in the two city reservoirs. 
Project: Ground water in the Bend-Redmond area, Joseph B. Gonthier, project chief

\section{Cooperator: Oregon Water Resources Department}

Project Period: 1977-80 (See “Progress"' below)

Description: This 700-square-mile area lies in the arid region east of the Cascades. Much of the surface is formed by young volcanic rocks which are cut by deep canyons so that ground water occurs in places at depths of several hundred feet. Although the area has large quantities of ground water, it is expensive to develop and good data are needed to limit development risks and costs. In places, liquid wastes, such as municipal sewage and storm runoff, have been disposed underground.

Objectives: To describe the hydrogeologic system, aquifer properties, and availability and quality of water in the major and perched aquifers. Maps will be prepared depicting distribution, thickness, and waterbearing characteristics of each aquifer. Other maps will show features of ground-water bodies, such as water levels, quality, availability, and recharge and discharge.

Progress: Work on the project has been temporarily discontinued, but will be resumed when work is started (in 1981) on the Deschutes Basin appraisal study into which this project will be integrated. Field data have been obtained for about 800 wells and water-level fluctuations measured in a series of representative wells for 3 years. Chemical analysis have been made of water from wells. Maps have been prepared showing well locations, water levels, and other data.

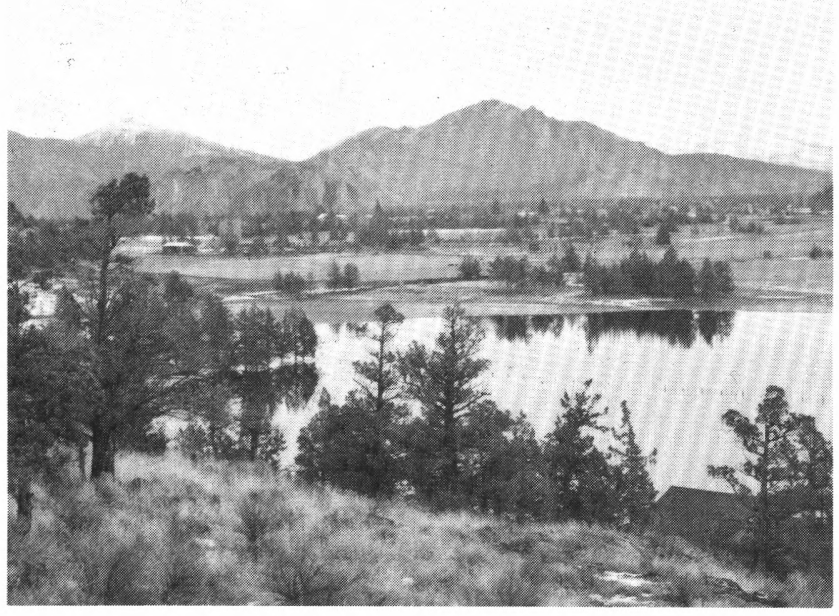

Project: Water resources of western Douglas County; D. A. Curtiss, project chief

\section{Cooperator: Douglas County}

\section{Project Period: 1978-81}

Description: This 850-square-mile coastal area is largely forested uplands and about half is managed by Federal and State agencies. Population is concentrated along the river valleys and near the coast. Winter precipitation and runoff are high, but the rocks provide little storage so small streams have very low summer flows. Coastal dune lakes are numerous, and the dune sand is the only sizable aquifer.

Objective: To determine the availability, variation, distribution, and quality of the ground and surface waters, including water in the lakes, rivers, and estuaries. The hydraulic characteristics of the aquifers will be determined and data obtained on the saltwaterfreshwater relations in the Umpqua River estuary.

Progress: Miscellaneous measurements have been made and water-quality data collected at eight ungaged stream sites. An inventory of about 150 wells indicates that well yields generally are low and the conductivity of ground water locally is quite high. The saltwater wedge in the estuary has been defined under low-flow, high-tide conditions. Data have been obtained on volume, level, and quality of eight coastal lakes, including biological characteristics and seasonal data for two. Fieldwork has been completed and the interpretive report is in preparation.

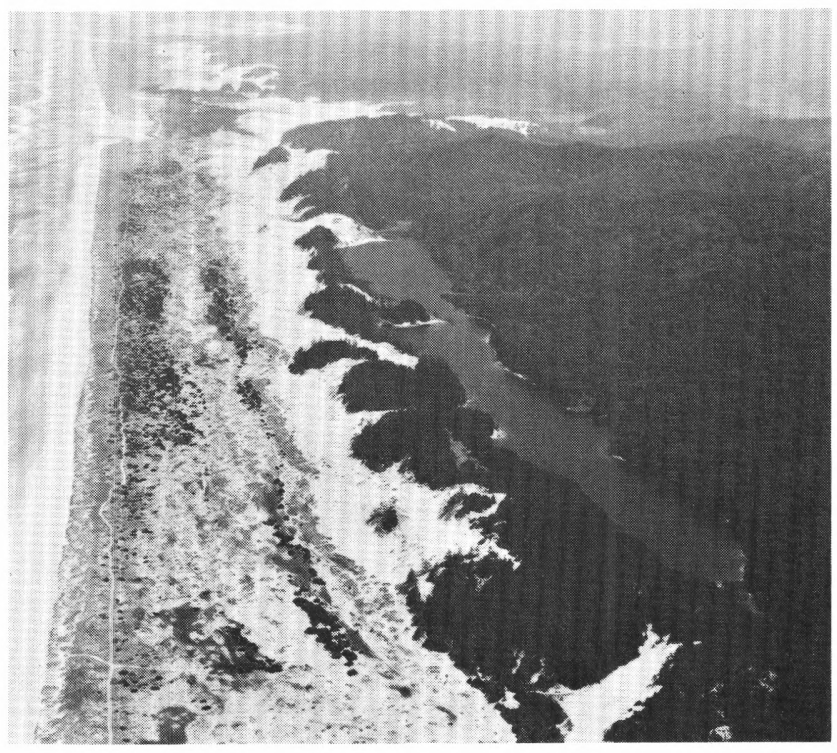


Project: Digital-simulation model of Portland well field; James E. Luzier, project chief

\section{Cooperator: City of Portland}

\section{Project Period: 1978-82}

Description: The city of Portland is developing a well field adjacent to the Columbia River east of the city. The area is underlain by a thick series of fluvial sediments, including thick sand and gravel beds some of which are tapped by local water districts for public supply. The city has identified four separate acquifers, at least one of which is in hydraulic connection with the Columbia River. Plans are to develop $100 \mathrm{Mgal} / \mathrm{d}$ from production wells as much as 1000 feet deep. A simulation model is needed by the city to plan construction, to manage the well field, and to evaluate the long-term effects of pumping on the aquifers and on other users.

Objectives: To develop a 3-dimensional, multi-aquifer flow model that can be used by the city as a predictive tool in developing ground water in the area and managing the well field. The model is expected to be capable of water-budget analysis and of predicting head distribution in each of at least three quifers for any proposed pumping rate or for continuous operation of the well field concurrently with other users.

Progess: Preliminary model analysis has been done, including calibration of pumping tests from parts of the well-field area. The model is being modified and calibration refined and extended, based on results of preliminary modeling and continuing well-field development. The preliminary model is being used by the cooperator to guide the present phase of development, select aquifers for exploitation, and to size and locate production wells.

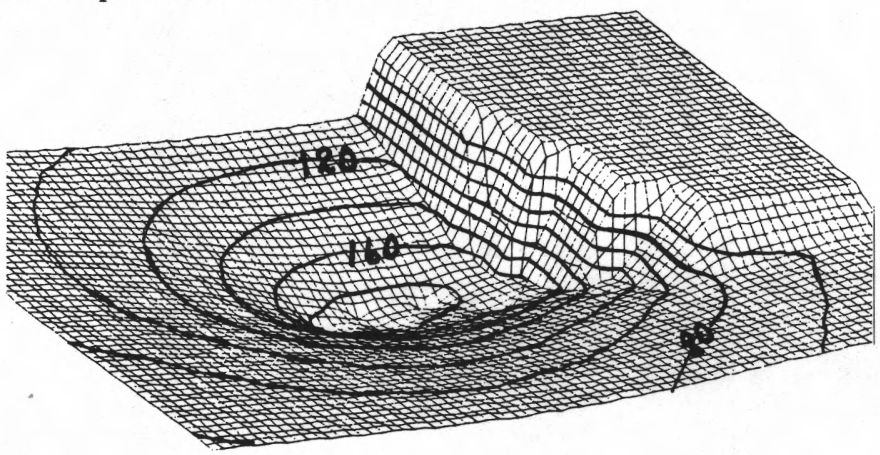

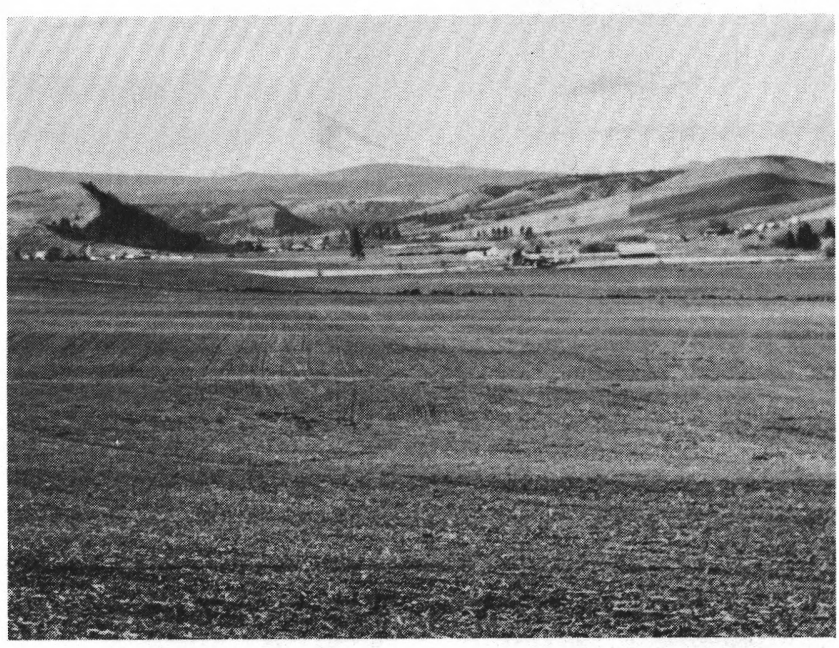

Project: Ground water in the Hood Basin; Stephen J. Grady, project chief

\section{Cooperator: Wasco County}

\section{Project Period: 1979-81}

Description: Aquifers in the Columbia River Basalt are the principal sources of water for much of the 900square-mile project area in Hood River and northern Wasco Counties. Ground water is being developed rapidly adjacent to the major towns and also is used extensively for irrigation. About $20 \mathrm{mi}^{2}$ was declared a “critical ground-water area" in 1964, and groundwater use is restricted there. Aquifers in the basalt are erratic in occurrence and their hydrologic characteristics contribute to water-supply problems.

Objectives: To obtain information on ground-water features in the basin and the geologic features that control them, especially in the developing areas. This includes determining the physical and hydrologic properties of the acquifers, their boundaries, the potentiometric surfaces, quality of water, and pumpage.

Progress: Most of the planned field data have been collected, including inventory of 438 wells, measurements of water levels, geophysical logging of selected wells, and collection of water samples for quality analysis. Preparation of maps and an interpretive report is underway.

Computer-generated plot of drawdown. 
Project: Salem urban storm-runoff study; Antonius Laenen, project chief

\section{Cooperator: City of Salem}

Project Period: 1978-83

Description: Both the volume and peak discharge from storms may be increased as a basin is changed from natural to urban. In the 70-square-mile Salem area, data are needed to assess the magnitude and frequency of urban storm runoff from small stream basins. The analysis of similar data from the Portland area may produce results applicable to basins with similar characteristics in the Salem area.

Objectives: To define the regional relations between storm rainfall and runoff for small streams in the Salem urban area. Runoff volumes and peaks will be related to basin characteristics, including land use, to storm sizes and magnitudes, and to other pertinent factors. Statistical analysis will be used to characterize those relationships.

Progress: Storm-water runoff stations have been set up at eight stream sites, and 14 rainfall, and nine creststage stations established. Precipitation and runoff data have been measured at those stations for 4 storms during the winter of 1978-79, and 11 during 1979-80. Data also have been obtained on the characteristics of the 16 selected drainage basins.

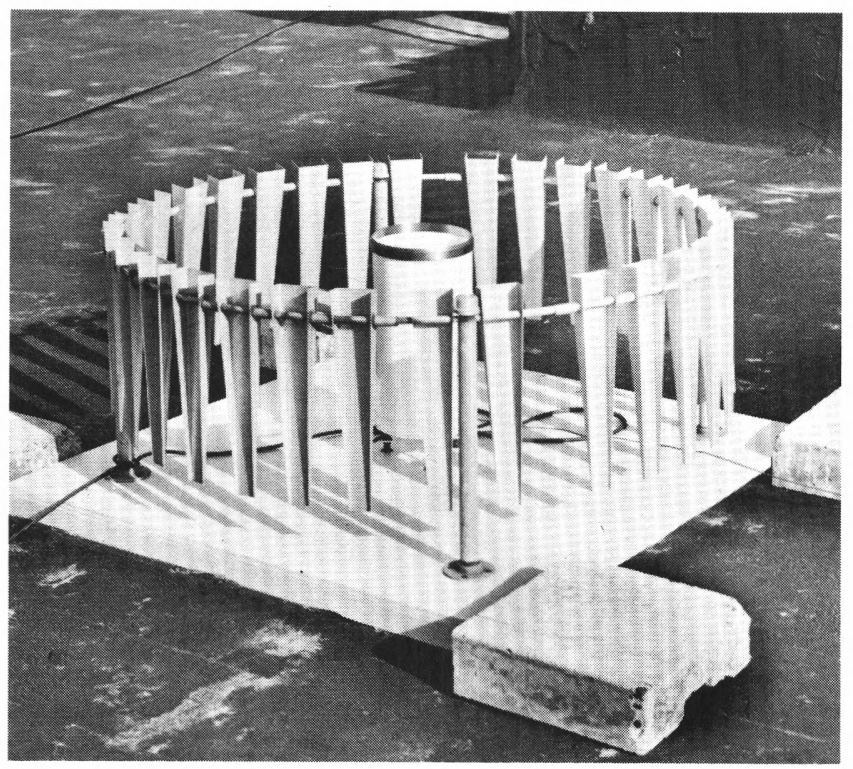

Project: Salem urban storm-water quality; Timothy L. Miller, project chief

Cooperators: Mid Willamette Valley Council of Governments and city of Salem

\section{Project Period: 1979-83}

Description: Storm runoff in the 70-square-mile Salem urban area carries contaminants into streams from streets, atmospheric fallout, and from material generated by residential and commercial areas, from farms and orchards, and industry. The water-quality problems associated with such runoff need to be defined and quantified. Studies in other areas show some contaminants may be related to land-use practices or to basin or storm characteristics.

Objectives: To describe the quality of storm-runoff water in streams in the Salem urban area. Also, to define statistical relationships between quality constituents and storm or basin characteristics. Relationships developed from the Portland area will be tested to see if they can be transferred to the Salem area.

Progress: Ten stream basins were selected for sampling and data collected from three storms during the winter of 1979-80. Additional data are being collected.

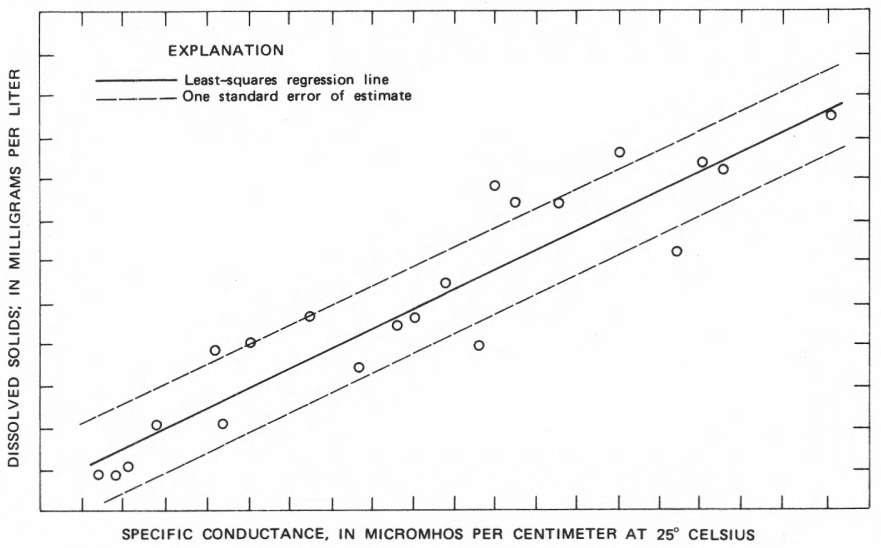

Stream-basin data-regression plot. 
Project: Iron geochemistry in Coos Bay dunes aquifer, James E. Luzier, project chief

Cooperator: Coos Bay-North Bend Water Board

Project Period: 1979-81

Description: The dune aquifer north of Coos Bay is one of the principal water sources for public and industrial water supplies in the Coos Bay area. Part of the area, near the sea, is a deflation plain which becomes inundated during the wet season. The decay of seasonal vegetation is believed to be responsible for high concentrations of dissolved iron in shallow zones of the aquifer. Because of the iron, water from some wells is usable only with expensive treatment or is not suitable for some uses.

Objectives: To describe and explain the source, distribution, and occurrence of iron in the aquifer under both natural and pumping conditions. Also, develop an iron-transport model (digital) to predict the movement of iron within the aquifer.

Progress: Wells have been constructed on a line extending $600 \mathrm{ft}$ inland from the beach. One well is screened in the deep zone so it can be test pumped. The other wells have tubes installed in several depth zones for sampling and obtaining data on heads and water quality. Some field tests have been made, and preliminary work on development of a digital transport model is underway.

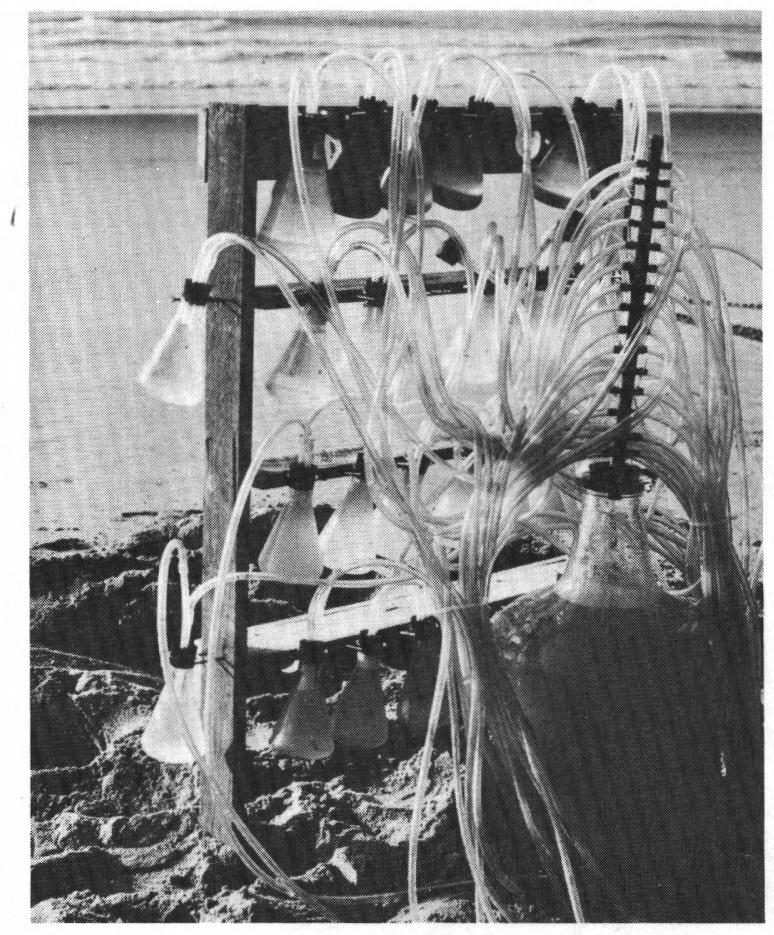

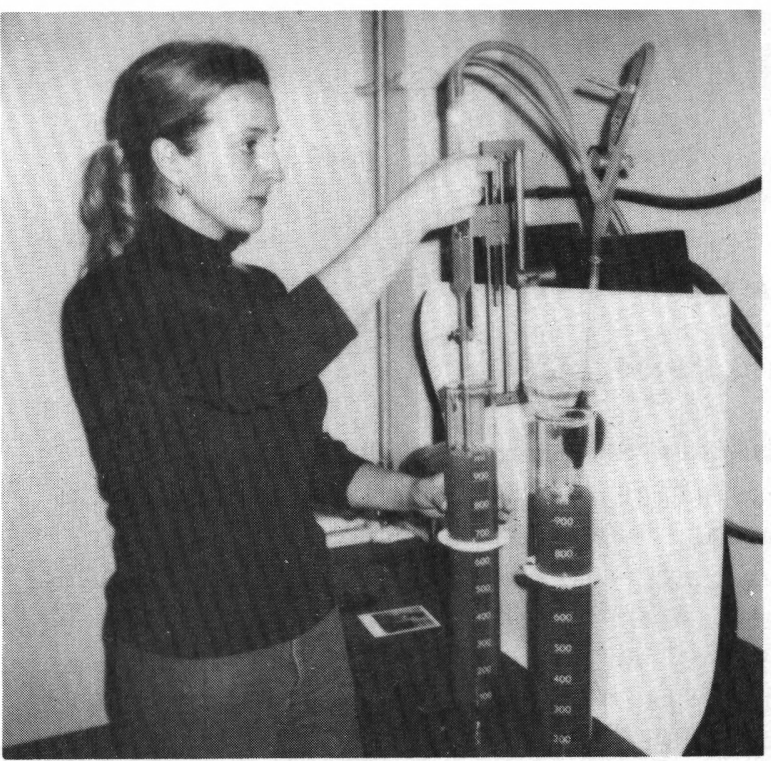

Project: Relation of settling velocity to constituent concentrations, Joseph F. Rinella, project chief

Cooperator: U.S. Geological Survey research project

Project Period: $1979-81$

Description: The interrelationship among particle size, settling velocity, and constituent concentrations in urban runoff is unknown. Information is needed to better relate the concentrations of toxic metals (such as cadmium and lead), nutrients, and organic materials to size and settling rates. Some constituents seem to be related to sand-size particles so that a large percentage might be easily removed by allowing short-term settling. Other constituents may settle in higher proportion to the silt than the clay fraction.

Objective: To develop methods for relating settling velocity to concentrations of particular constituents and to analyze the variations in constituent-settling velocity during parts of a storm cycle and for different storms and basins.

Progress: Tests were made on storm-runoff samples collected at two sites in the Portland area during the winter of 1979-80. Quantitative, determinations were made of relative concentrations of cadmium and lead for particle sizes larger and smaller than 62 um and for dissolved constituents. It was noted that the shape of particles (which defines their surface areas) determines their settling rate, and hence apparent particle size. Testing methodology may be adjusted to produce better results during the next winter storm period of intensive sampling. 
Project: Ground-water resources in Rogue River basin, Joseph B. Gonthier (U.S. Geological Survey) and William Bartholomew (State), project chiefs

\section{Cooperator: Oregon Water Resources Department}

\section{Project Period: 1979-82}

Description: This is the first of a series of comprehensive basin ground-water projects. The 5,000-squaremile basin encompasses an area of diverse geology, terrain, climate, and land use. A large percentage of the basin is in national forests, including primitive areas and national scenic rivers. The basin headwaters are in the volcanic slopes of the Cascades and the western part in the highly dissected coastal mountains formed of ancient granites, ultramafic rocks, and sediments. The most heavily populated areas are the interior valleys near Ashland, Medford, and Grants Pass. Ground water is the principal source for domestic supplies in the rapidly expanding areas near those cities as well as smaller communities along the Rogue River and the principal highways.
Objectives: To appraise and quantify ground water in each aquifer in the basin. Maps will be developed showing all important aquifer properties such as thickness, transmissity, boundaries, areal extent, and geologic features. Other maps will show principal features of ground-water bodies such as head, recharge, storage capacity, availability, use, and quality. The report and accompanying maps can be used to guide land-use planning; develop and manage the water resources; and plan for artificial recharge, waste disposal, and waterquality regulation.

Progress: Work on the project was started in the summer and fall of 1979. The main effort to date has been to inventory wells, measure water levels, obtain wateruse data, construct preliminary maps, and to prepare well data for the ADP system. Field data collection was completed in 1980 and work on data compilation and report preparation is underway.

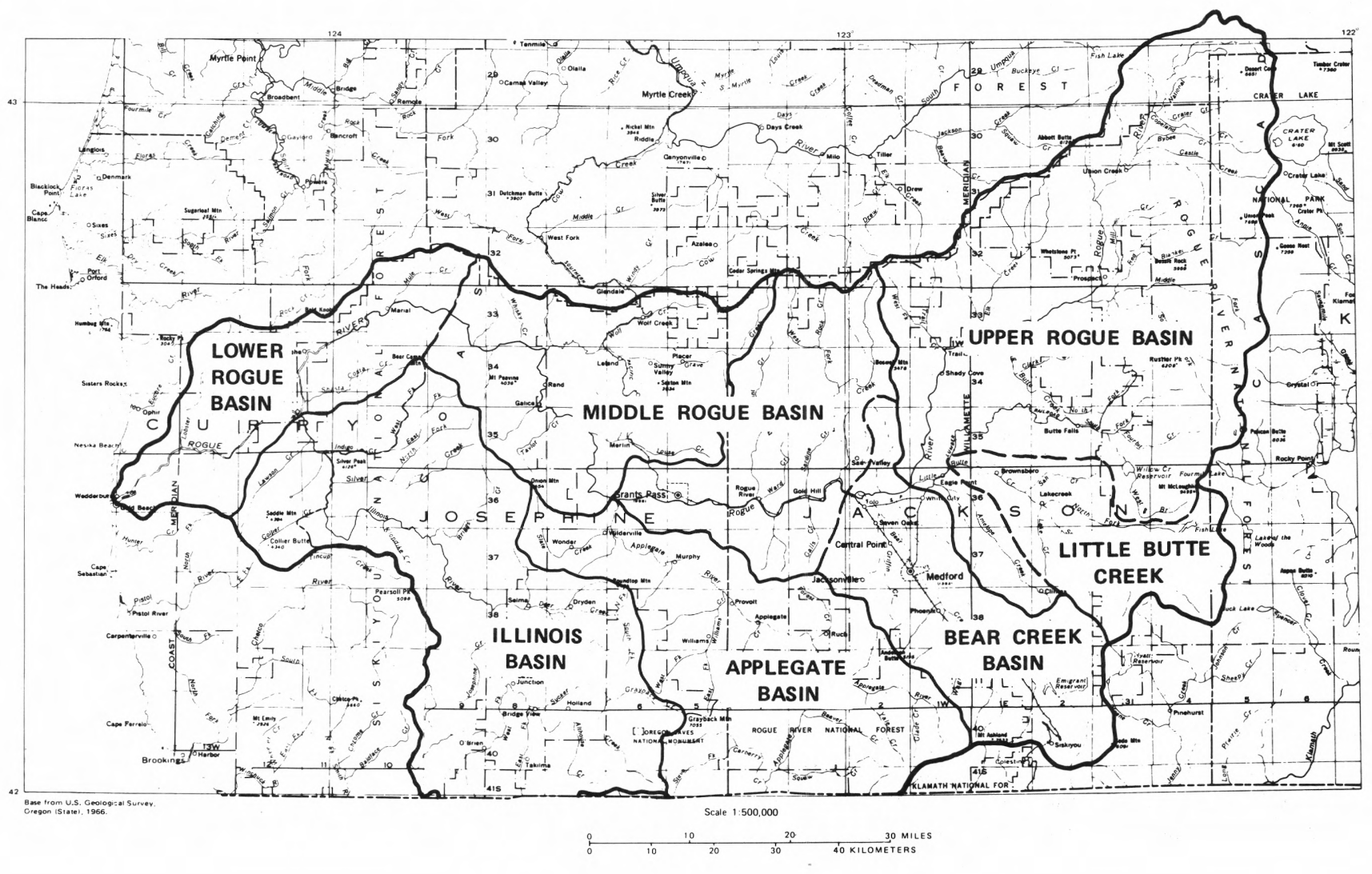

Subbasins in Rogue River basin. 
Project: Progress and operation of acoustic velocity meters, Antonius Laenen, project chief

Cooperator: U.S. Geological Survey research project

Project Period: 1979-81

Description: In 1969, the Oregon District installed the first acoustic velocity meter (AVM) on a large river, the Columbia, in the United States. The Survey now has six AVM's in operation-two in Oregon and three in Washington. Although AVM's now available operate satisfactorily and require little maintenance, they are expensive and their advantages are not well known to most hydrographers.

Objective: To obtain information on the operation of AVM's throughout the world and to report on their operation, performance, application, and limitations.

Progress: Contacts have been made with and data obtained from AVM users outside the Survey. Work has been started on the report of project findings.

Project: Acoustic velocity meter feasibility study, Antonius Laenen, project chief

Cooperator: U.S. Geological Survey research project

Project Period: 1979-81

Description: The AVM is known to be a technically sound system for measuring the flow of streams. However, information is not available on the availability of cost-effective AVM systems that might be more widely used than at present. Recent developments in electronics, including minicomputers, indicate the potential for more widely adaptable, low-cost systems.

Objective: To obtain information from AVM suppliers and users on AVM equipment now available. Also, to provide data to aid the Survey in expanding the use of acoustic techniques on a cost-effective basis.

Progress: AVM vendors, both domestic and foreign, have been contacted to obtain information on available equipment, techniques, and costs. A progress memorandum, assessing that informtion, has been written.

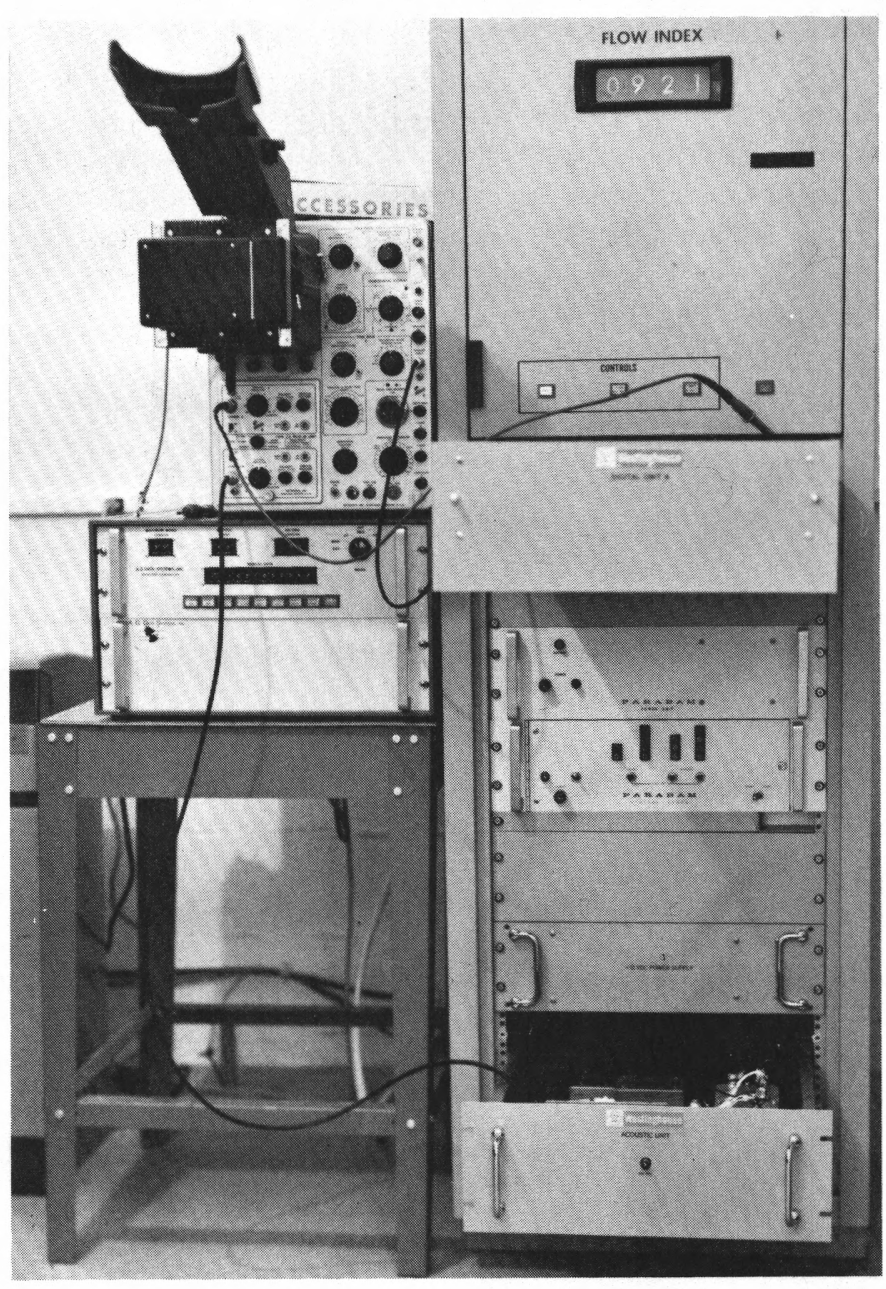


Project: Ground-water model, Umatilla structural basin; Ann Zurawski, project chief

Cooperator: Oregon Water Resources Department

Project Period: 1980-84

Description: Irrigation has expanded rapidly in the 5,000 -square-mile study area in the last 20 years. More than 100,000 acre-feet of water is now pumped annually from the Tertiary basalt in the Oregon part of the basin. Water levels have declined over a wide area, in places more than 150 feet, requiring the deepening of some irrigation wells and new wells to be drilled in places. The State has an intensive data-gathering program in the area to provide information needed for future regulatory decisions.

Objective: To develop a three-dimensional transientflow model simulating ground-water flow in the basalt aquifers. This model will be designed to show the response of the complex aquifer system to different pumping rates and distribution schemes. The geologic framework and natural boundaries of the hydrologic system will be identified; aquifer properties, recharge and discharge areas, flow directions, water levels, and rates of pumping will be determined; and estimates made of rates of recharge and leakage, and of the quantity of water in storage.

Progress: Hydrologic records are being assembled and put into computer storage for use in the model. These records include data on well location, water use, and historical and current water levels. Work also has begun to obtain data on quantities and distribution of historical water use and the development of a preliminary steady-state model.

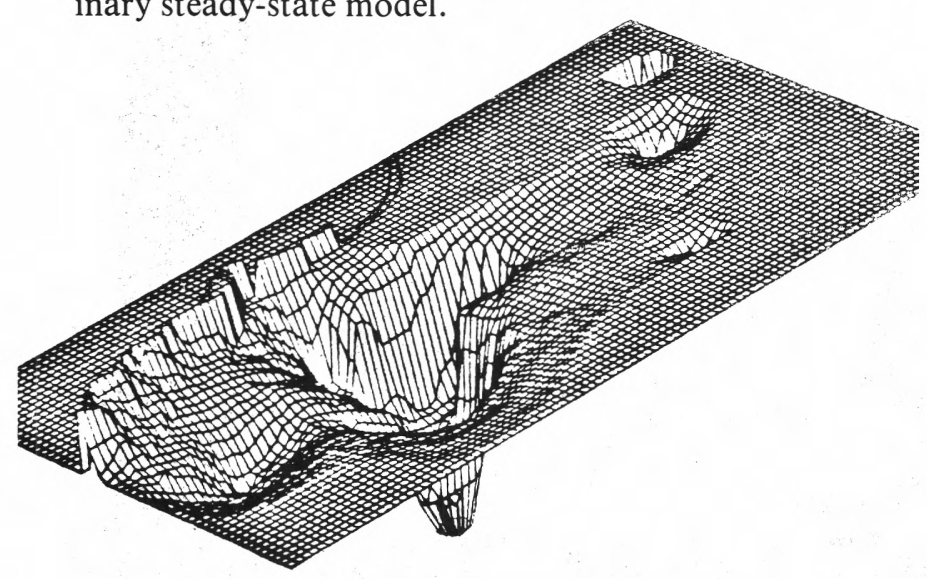

Computer-generated water-level net.
Project: Data for underground-injection-control program; David D. Harris, project chief

Cooperator: Environmental Protection Agency

Project Period: March 1980-May 1981

Description: Control of underground injection of liquid wastes is necessary to protect ground-water sources potentially suitable for drinking water supplies. To assist EPA in assessing the impact of injection in the area west of the Oregon Cascades, the Survey will identify, describe, and determine the hydrologic properties of all aquifers in the project area. Maps and cross sections also will be prepared showing the thickness and water-table elevations of each aquifer and levels of dissolved solids in the ground water.

Objective: To identify and define the extent of all aquifers in western Oregon that contain water with less than $10,000 \mathrm{mg} / \mathrm{L}$ dissolved solids. To collect data on hydrologic properties of potential injection zones sufficient to determine distance that injected wastes might move.

Progress: Data-collection phase of project is underway.

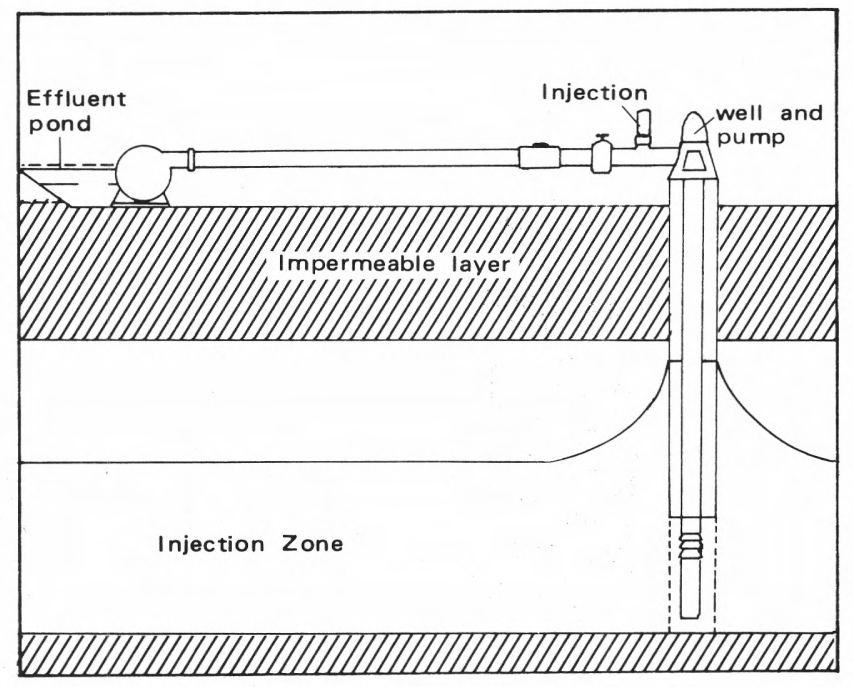

Diagram of underground injection-control system. 
Project: Impacts of coal development on water resources; G. G. Parker, project chief

\section{Project Period: February 1980-September 1980}

Description: Millions of tons of coal in southwestern Oregon could be developed to supply local energy needs. The major deposits are adjacent to an important estuary, Coos Bay, and to the Coquille River and the Pacific Ocean. Besides the southwestern coal deposits, additional minor deposits of coal have been reported from other areas in the State. Oregon also has other geoenergy resources such as the small gasfield in northwestern Oregon and major geothermal resources in the Cascades and southeastern part of the State. Large acreages are under lease for geothermal or oil and gas exploration.

Objectives: To identify and describe briefly the occurrence of coal and other geoenergy resources in Oregon and to examine the potential hydrologic impacts of developing those resources.

Progress: A comprehensive review of published reports on Oregon geoenergy resources has been completed and available information obtained from State agencies and commercial sources. A draft report is in review and is expected to be released in 1981 .

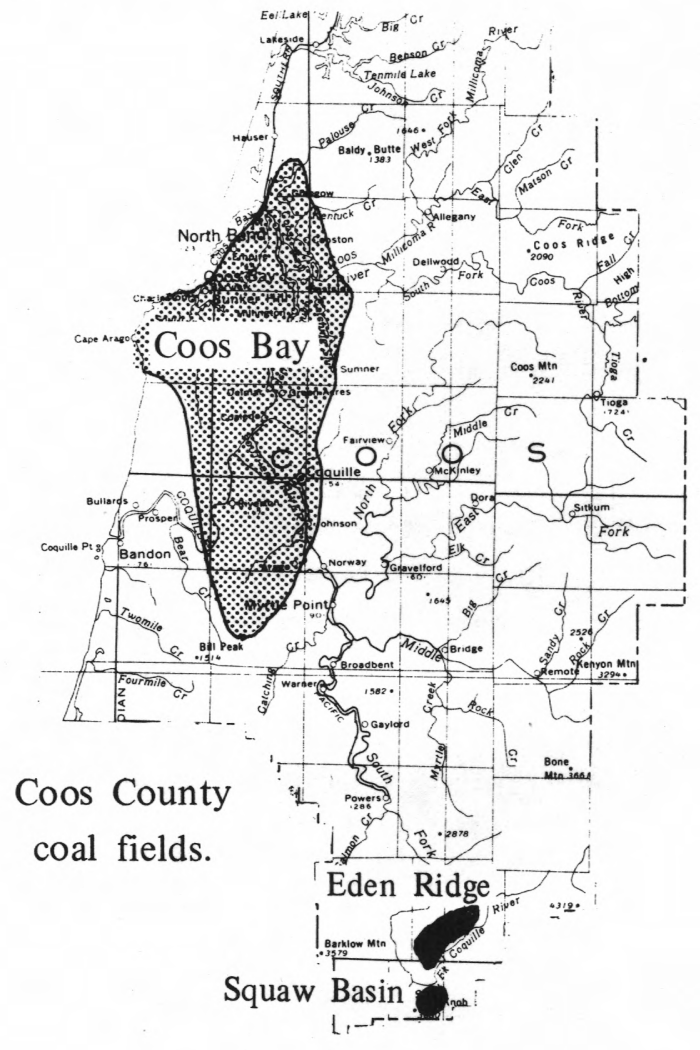

Project: Impact of Mount St. Helens ash on water resources; S.W. McKenzie, Project Chief.

Cooperator: U.S. Geological Survey research project.

\section{Project Period: Continuing.}

Description: Volcanic ash and gases discharged into the atmosphere due to Mount St. Helens volcanic activity affect the quality of Oregon's water resources. These emissions could produce acid precipitation which would lower the $\mathrm{pH}$ and raise the acidity and specific conductance of surface waters. Dry ash fallout also could alter water quality due to its solubility and as it was carried into streams and reservoirs by runnoff.

Objectives: To document the effects of Mount St. Helens volcanic activity on precipitation, bulk precipitation chemistry, and dry fallout. Also to document the effects on precipitation in the Bull Run watershed and assess those effects on the quality of Portland's water and supply.

Progress: Seven precipitation samplers have been installed, samples were collected several times from 7 streams and 2 lakes, and suspended-sediment samples collected from the Columbia River. Additional rain gages and wet fallout collectors are being installed. U.S.G.S. Circulars will be prepared in 1981, on sediment, elutriate, and bottom materials from the Columbia River, and on the effect of ash on Oregon water resources.

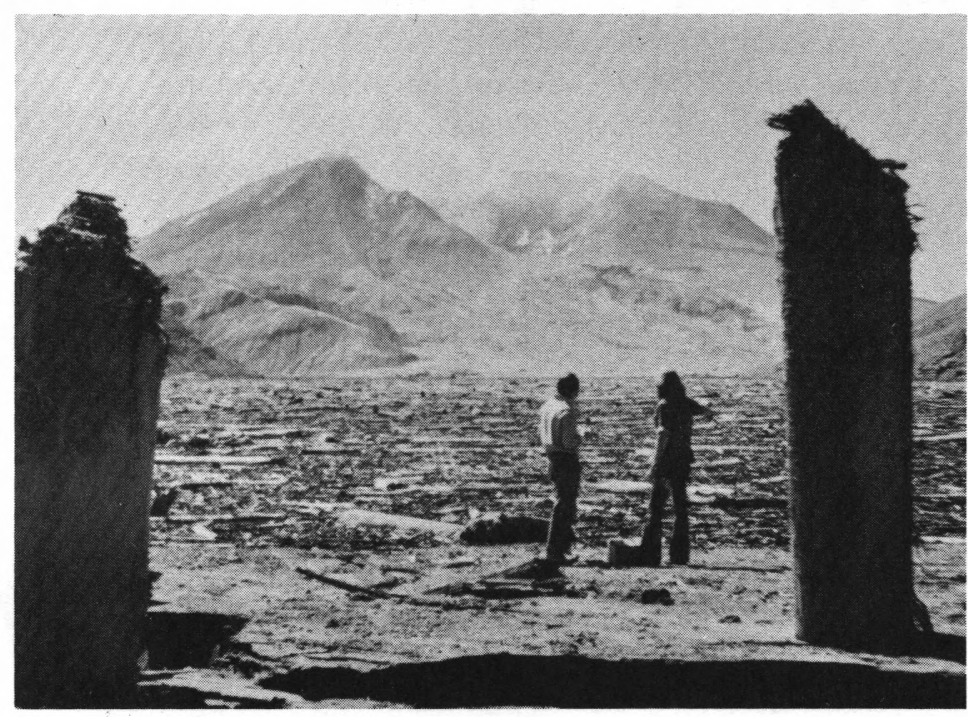




\section{Other Hydrologic Work by the District is Varied}

As part of its responsibility to provide information on water to all water users, the Geological Survey is involved in numerous other activities in addition to regular programs of data collection and hydrologic investigations. One of these functions is to serve as a Federal or Survey representative on advisory committees or ad hoc groups set up for specific purposes. For instance, the Division participated actively in both the Willamette Basin and Columbia River comprehensive studies a few years ago. Some of the current special activities are described below:

Director's representative.-The District Chief serves as the Oregon representative of the Geological Survey Director to provide a local point of contact and to supply information on the work in the State of all divisions. He also is a member of the Pacific Northwest Field Committee, the Portland Federal Executive Board, and the Bull Run Advisory Committee.

\section{Committee and Task Force memberships.-Members} of the District Staff are working members and advisors to a large group of committees and task forces. Included are The Columbia River Estuary Study Task Force, Oregon Estuarine Research Council, Federal Agency Task Force for Oregon Coastal Zone Program, and Water Subcommittees for Mid Willamette Valley and Rogue Valley Councils of Governments, Federal Water Management Committee, Oregon Interagency Pesticide Council, and State Map Advisory Committee.

\section{Review of Environmental Impact Statements and other} agency reports. - The Water Resources Division reviews Environmental Impact Statements for Federal airport and highway projects to insure that available hydrologic data are used, that they are used correctly, and that the impact of construction on water features and resources is accurately evaluated. From time to time, the District is also asked to review reports and projects of other Federal agencies, primarily because of the Survey's hydrologic expertise and impartiality.

Assistance to other agencies and individuals. - In addition to the Survey's formal programs and studies, water information and assistance are provided other agencies with specific problems. For instance, to the National Park Service in exploring for water supplies in Crater Lake National Park and the Oregon Caves and John Day Fossil Beds National Monuments. The District continually receives calls, visits, and mail requests for information on ground-water availability, streamflow data, and water quality from landowners, consultants, public officials, and business concerns. Federal regulations prohibit activity that encroaches on the work of professional consultants, but much information and assistance are provided to professional engineers, geologist, and other consultants.

Special activities. - The District is regularly called on for certain work not covered under specific projects or data-collection programs. These include obtaining hydrologic data to document drought effects and indirect flood measurements, both in Oregon and other states that have suffered flood disasters. Also included is research-type work such as the experimental testing of the Middelburg sample splitter. One ongoing research activity is the operation of 10 Geostationary Observational Environmental Satellite (GOES) platforms in the Bull Run River basin. Hydrologic data from those stations are transmitted via satellite to provide a continuing record of "real-time" data on precipitation and river and reservoir stage.

Considerable additional work has been required by District people as a result of the recent volcanic activity at Mount St. Helens in southwestern Washington. The aeronautical expertise of the District Chief has been used to provide aerial reconnaissance and observation as well as oblique photography of volcanic activity. The District also has furnished clerical help and other assistance to Survey geologists, administrators, and information officers. Analyses were made of precipitation, stream water, and ash associated with ash fallout in the Bull Run watershed in April-June (see Open-File Reports 80-593 and 80-740). Several people in the District have collected samples of ash that fell in the Portland area to determine the ash volume and to analyze the effects of the ash on precipitation and water quality. Several hydrologists and technicians from the District assisted personnel of the Washington District in making indirect flood measurements along the Cowlitz and Toutle Rivers following the disastrous mudflows and floods from the May 18 eruption. Both the Oregon and Washington District Chiefs have made presentations of Water Resources Division work to press briefings at the Mount St. Helens study office in Vancouver. They also have attended briefings and informational meetings to keep abreast of studies and activities associated with the eruptions. 


\section{Reports are our Most Important Products}

Reports prepared and released since 1977 are listed on the following pages. Most recênt reports were issued locally as open-file or water-resources investigations reports which include map reports, data reports, and interpretive reports. A few ground-water reports are in the State Water Resources Department Ground Water Report series. The series of 715 Circulars were prepared as part of the Survey's Willamette Intensive River Quality Assessment Study.

Ground-water reports.-Ground-water reports for more than 60 areas in Oregon have been prepared since 1945 . These reports include water-supply papers, professional papers, State ground-water reports, hydrolog- ic-investigations atlases, and open-file reports. Most describe the occurrence and availability of ground water for a specific area, but some are tabulations of data (map, p.25) and others cover artificial-recharge experiments, or special geologic features related to ground water. Locations of areal reports, except those for "spot areas" or small sites, are shown below. "Detailed" reports are those having water-level maps or sufficient statistical data on wells that most common questions concerning ground-water development for a specific site can be answered. The "less detailed" reports contain much useful information, but generally much fewer data than the detailed.

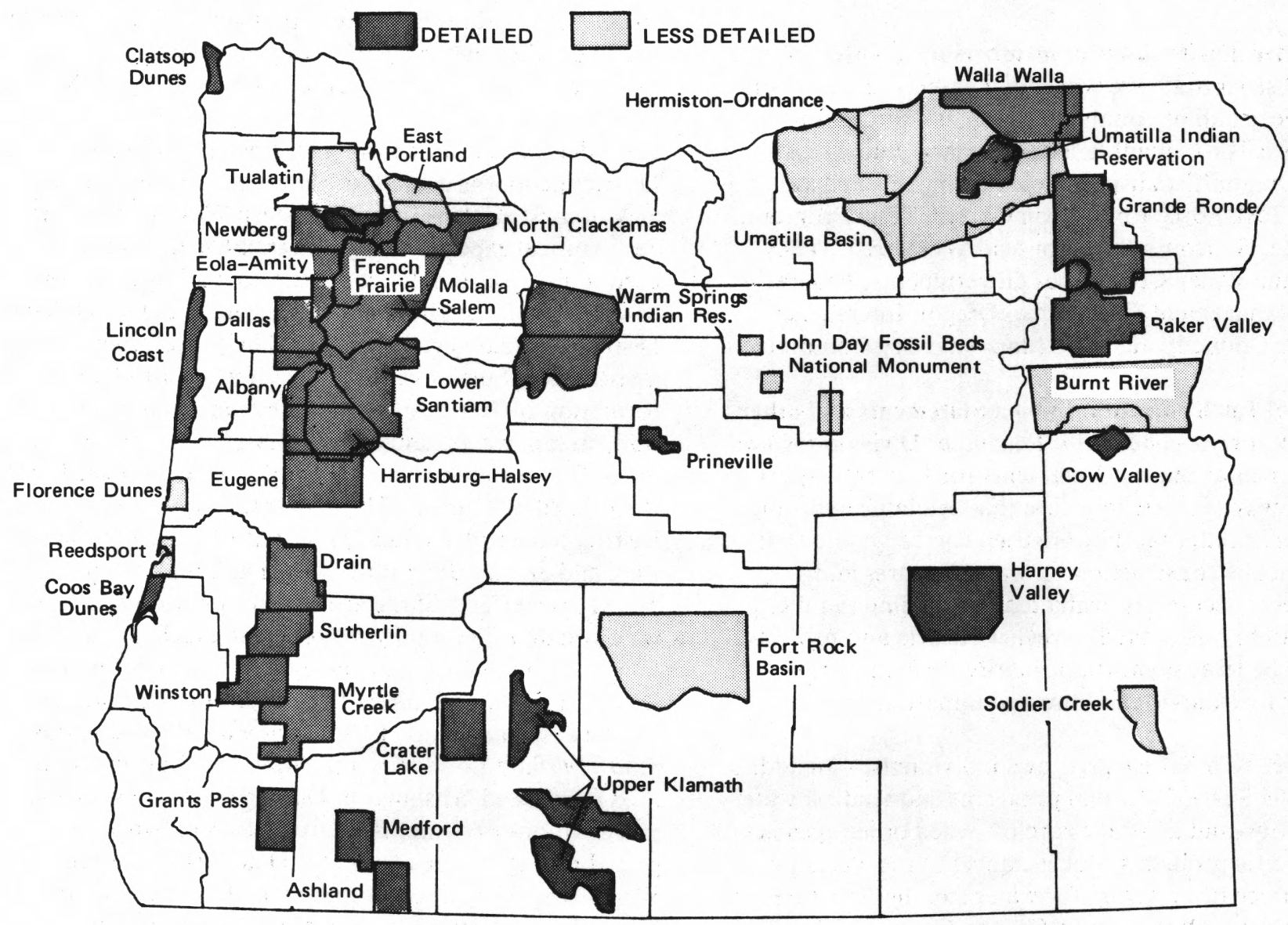

Areas covered by interpretive ground-water reports. 
Lake reports.-Since 1971, six reports have been issued presenting inventories of all lakes and reservoirs larger than 5 acres. Those reports, shown in figure 00 , give data on location, size, water quality, and recreational use for lakes in the following 13 counties of western Oregon:

Clatsop, Columbia, Tillamook Counties ..... Volume 1 Benton, Lincoln, Polk Counties ........... Volume 2 Hood River, Multnomah, Washington,

Yamhill Counties Volume 3

Clackamas County .................... Volume 4

Marion County ....................... Volume 5

Douglas County .................. Volume 6

Other recent lake studies by the Geological Survey, shown on the map, include water budgets for Upper Klamath (HA-351) and Malheur Lakes (WRI 21-75); studies of the hydrology and chemistry of Crater, East, and Davis Lakes (WSP 1859-E); and geochemistry of Abert, Summer, and Goose Lakes (PP 502-B).

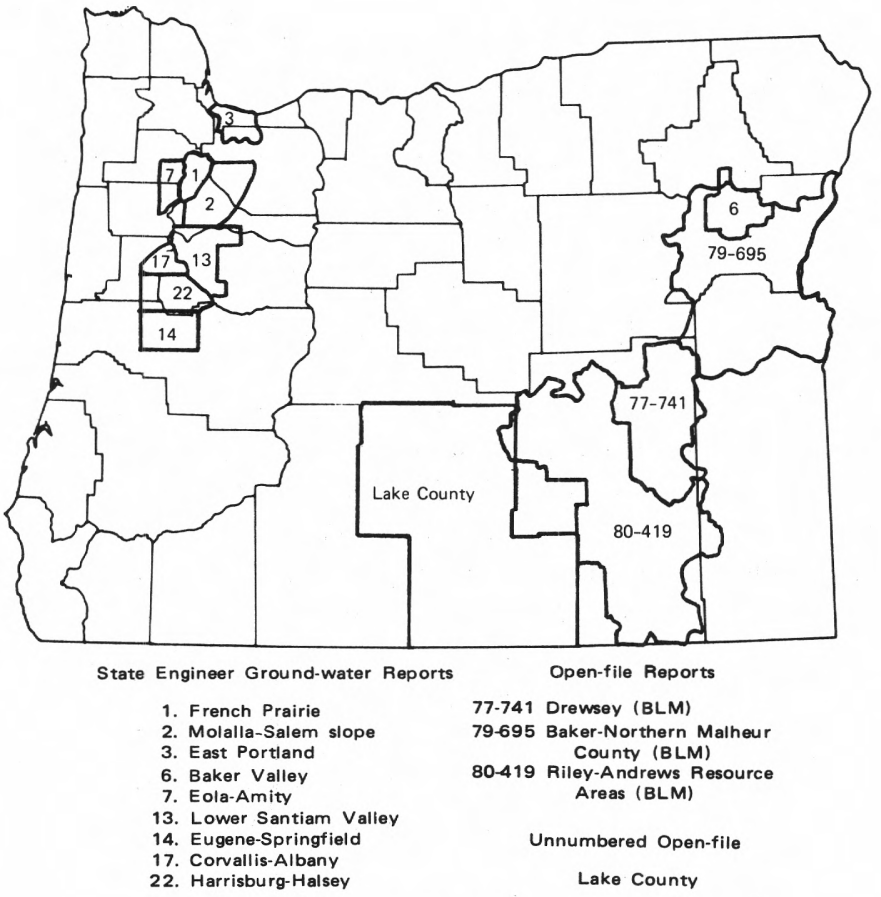

Ground-water data reports.

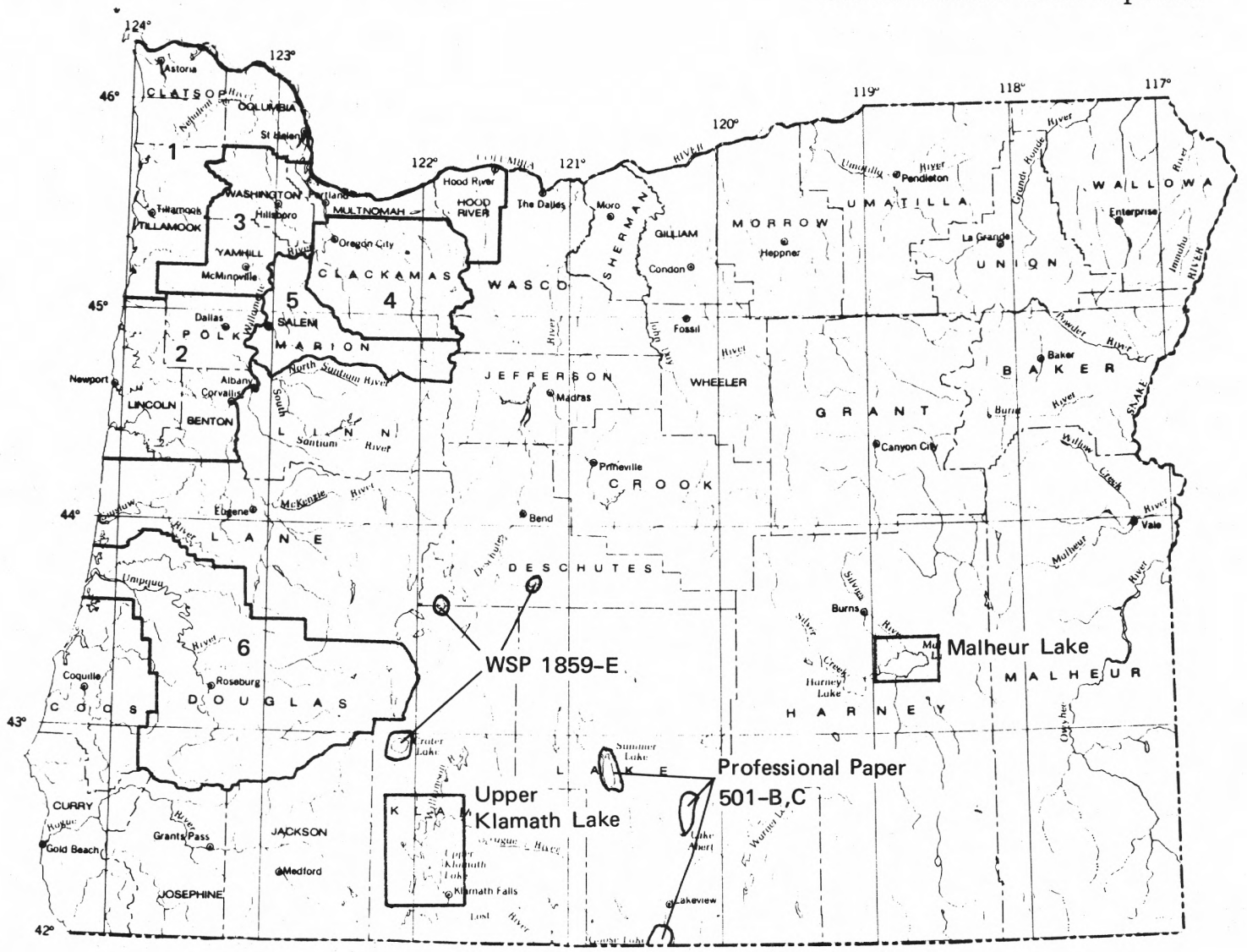

Lake reports in Oregon. 


\section{Numbered Open-file Reports}

77-90. 1976 water-quality data in Bear Creek basin, Medford, Oregon, by S.W. McKenzie and L. A. Wittenberg. 1977.

77-740. Analysis of bottom material from the Willamette River, Portland Harbor, Oregon, by S.W. McKenzie. 1977.

77-741. Ground-water data for the Drewsey Resource Area, Harney and Malheur Counties, Oregon, by J. B. Gonthier, C. A. Collins, and D. B. Anderson. 1977.

77-799. Preliminary summary - Analysis of urban storm-water quality from seven basins in the Portland area, Oregon, by T. L. Miller and S.W. McKenzie. 1977.

78-28. Elutriation study of Willamette River bottom material and Willamette-Columbia River water, by J. F. Rinella and S.W. McKenzie. 1978.

78-230. Hydrologic data in Bear Creek basin and western Jackson County, Oregon, 1976-77, by L. A. Wittenberg and S.W. McKenzie. 1978.

78-291. Rainfall-runoff data for selected basins, Portland, Oregon, and Vancouver, Washington, by Antonius Laenen and G. L. Solin. 1978.

78-554. Monitoring water-quality aspects of pilot dredging operations in the Willamette and Columbia Rivers, by J. F. Rinella and S.W. McKenzie. 1978.

78-662. Analysis of urban storm-water quality from seven basins near Portland, Oregon, by T. L. Miller and S.W. McKenzie. 1978.

78-680. Sediment sources and Holocene sedimentation history in the Tillamook Bay, Oregon: Data and preliminary interpretations, by $\mathrm{J}$. L. Glenn. 1978.

78-851. Urban storm-water quality data, Portland, Oregon, by T. L. Miller. 1978.

79-8. Ground water in the Myrtle Creek-Glendale area, Douglas County, Oregon, by F. J. Frank. 1979.

79-217. Storm-water data for Bear Creek basin, Jackson County, Oregon, 1977-78, by Loren A. Wittenberg. 1979.

79-553. Magnitude and frequency of floods in western Oregon, by D. D. Harris, L. L. Hubbard, and L. E. Hubbard. 1979.
79-695. Ground-water data in the Baker Countynorthern Malheur County area, Oregon, by C. A. Collins. 1979.

79-978. Benthic invertebrates, periphyton, and bottom material and their trace-metal concentrations in Salmon Creek basin, Clark County, Washington, by A. C. White and S. W. McKenzie. 1979.

79-1487. Water availability and flood hazards in the John Day Fossil Beds National Monument, Oregon, by F. J. Frank and E. A. Oster, 1979.

79-1535. Water-quality data from five Oregon stream basins, by T. L. Miller. 1979.

80-158. Water quality of Bear Creek basin, Jackson County, Oregon, by L. A. Wittenberg and S. W. McKenzie. 1980.

80-419. Ground-water data for the Riley and Andrews Resource Areas, southeastern Oregon, by P. J. Townley, C. M. Soja, and W. C. Sidle. 1980.

80-444. Evaluation of water-supply sources for the Reedsport area, Oregon, by J. F. Rinella, F. J. Frank, and A. R. Leonard. 1980.

80-593. Mount St. Helens ash fall in the Bull Run watershed, Oregon, May-June 1980, by M. V. Shulters and D. G. Clifton. 1980.

80-689. Magnitude and frequency of storm runoff as related to urbanization in the Portland, Oregon-Vancouver, Washington, area, by Antonius Laenen. 1980.

80-740. Mount St. Helens ash fall in the Bull Run watershed, Oregon, March-April 1980, by M. V. Shulters and D. G. Clifton. 1980. Oxygen demand in Portland Harbor, Willamette River, Oregon, by S. W. McKenzie (In review).

- Bathymetric data and sedimentation rates in Upper Klamath Lake, Oregon, with supplemental data for Lake Euwana, by G. G. Patterson, L. L. Hubbard, and Ann Martin (In review).

Dissolved-oxygen and algal conditions in selected locations of the Willamette River basin, Oregon, by F. A. Rinella, S. W. McKenzie, and S. A. Wille. (In review). Ground-water resources in the Hood Basin, Oregon, by S. J. Grady (in review). 


\section{Unnumbered Open-file Reports}

Miller, T. L., Rinella, J. F., McKenzie, S. W., and Parmenter, Jerry, 1977, Analysis of street sweepings, Portland, Oregon.

Rinella, J. F., 1977, Lakes of Oregon-Volume 5, Marion County.

1979, Lakes of Oregon-Volume 6, Douglas

County.

\section{Ground-water Reports}

27. Ground water in the Newberg area, northern Willamette Valley, Oregon, by F. J. Frank and C. A. Collines. 1978.

28. Ground-water resources of the Dallas-Monmouth area, Polk, Benton, and Marion Counties, Oregon, by J. B. Gonthier. 198 .

29. Availability of ground water in the northern part of Clackamas County, Oregon, by A. R. Leonard and C. A. Collines. 198 .

\section{Professional Papers}

813-S. Summary appraisal of the Nation's groundwater resources-Pacific Northwest Region, by B. L. Foxworthy. 1979.

1044-G. Hydrogeologic appraisal of the Klamath Falls geothermal area, Oregon, by E. A. Sammel. 1980.

\section{Circulars}

715-D. Hydrologic analysis and river-quality data programs, by W. G. Hines, D. A. Rickert, and S. W. McKenzie. 1976.
715-F. A synoptic survey of trace metals in bottom sediments of the Willamette River, Oregon, by D. A. Rickert, V. C. Kennedy, S. W. McKenzie, and W. G. Hines. 1977.

715-G. Algal conditions and the potential for future algal problems in the Willamette River, Oregon, by D. A. Rickert, R. R. Petersen, S. W. McKenzie, W. G. Hines, and A. Wille. 1977.

715-I. Dissolved-oxygen regimen of the Willamette River, Oregon, under conditions of basinwide secondary treatment, by W. G. Hines, S. W. McKenzie, D. A. Rickert, and F. A. Rinella. 1977.

715-J. Steady-state dissolved oxygen model of the Willamette River, Oregon, by S. W. McKenzie, W. G. Hines, D. A. Rickert, and F. A. Rinella. 1979.

715-K. Evaluation of planning alternatives for maintaining desirable dissolved-oxygen concentrations in the Willamette River, Oregon, by D. A. Rickert, F. A. Rinella, W. G. Hines, and S. W. McKenzie. 1980.

715-L. A synoptic approach for analyzing erosion as a guide to landuse planning, by W. M. Brown III, W. G. Hines, D. A. Rickert, and G. L. Beach. 1979.

850-A. Mount St. Helens volcanic-ash fall in the Bull Run watershed, Oregon, March-June 1980, by M. V. Shulters and D. C. Clifton, 1980.

\section{Other Publications}

Shulters, M. V., and Kapustka, S. F., 1980, The Bull run Reserve-Water-quality monitoring: American Water Works Association proceedings annual meeting 1980. 

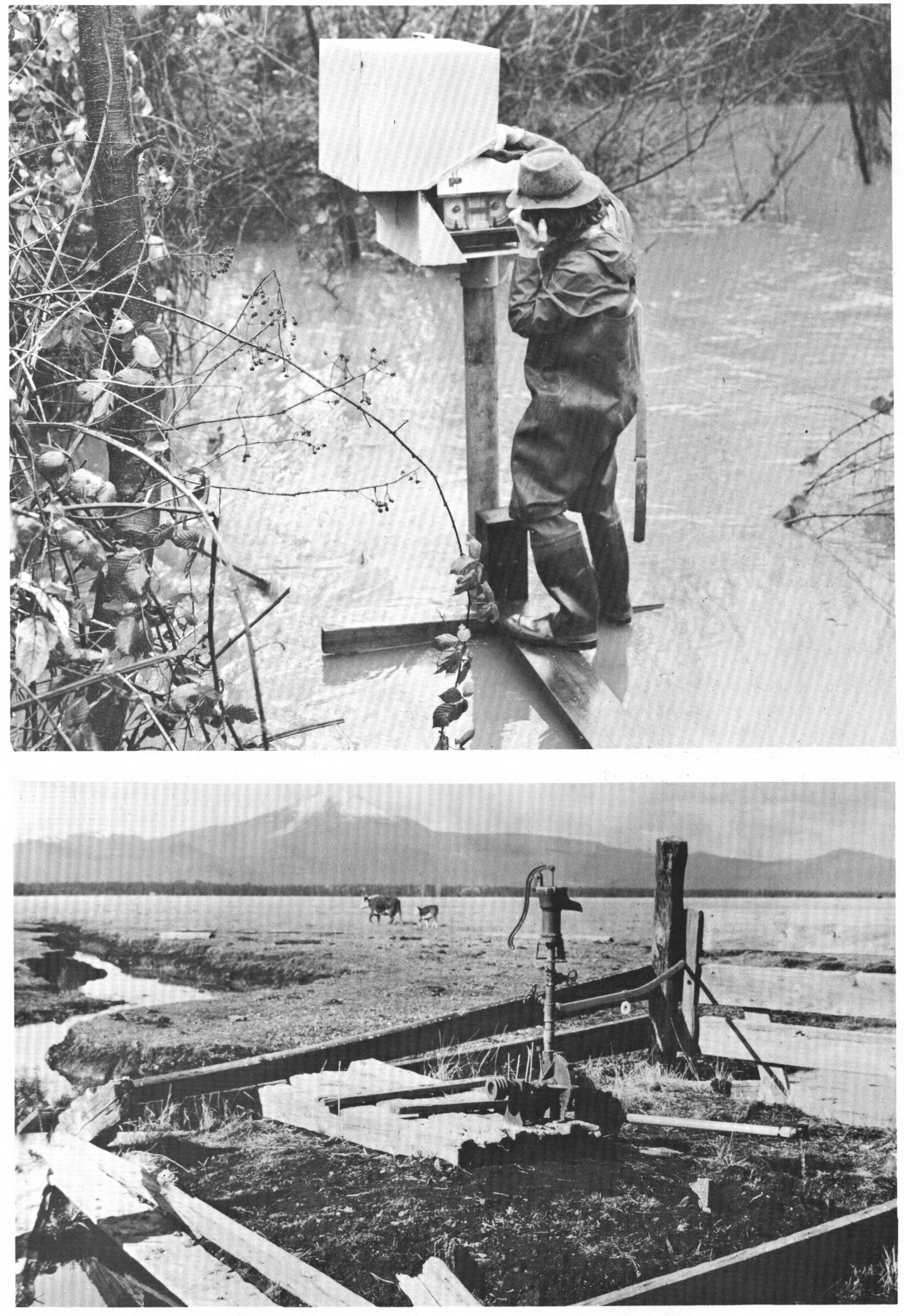


\section{For Information Contact:}

U.S. Geological Survey, Water Resources Division

National Center

Reston, VA 22092

Telephone:

(703) $860-6921$

U.S. Geological Survey, Water Resources Division Western Region Office

345 Middlefield Road

Menlo Park, CA 94025

Telephone:

(415) 323-8111

\section{District Office, Water Resources Division}

P.O. Box 3202

Portland, OR 97208

Telephone:

(503) 231-2008

S. F. Kapustka, District Chief . . . . . . . . . . 231-2009

E. L. Bolke, Associate District Chief ....... 231-2010

D. D. Harris, Asst. Dist. Chief,

Hydrologic Investigations . . . . . . . 231-2258

L. L. Hubbard, Asst. Dist. Chief,

Hydrologic Data ................ 231-2021

G. L. Gallino, Subdistrict Chief,

Portland ..................... 231-2023

Water-quality data and investigations,

S. W. McKenzie ................. 231-2016

Ground-water modeling projects,

J. E. Luzier . . . . . . . . . . . . . . . 231-2013

Ground-water basin and areal projects,

J. B. Gonthier
Field Headquarters

P. O. Box 1043

La Grande, OR 97850

W. D. Eicher, Technician-in-Charge

Telephone:

(503) $963-3560$

Field Headquarters

P. O. Box 808

Eugene, OR 97850

W. W. Higbee, Hydrologist-in-Charge

Telephone:

(503) 687-6446

\section{Field Headquarters}

1019 N. Riverside

Medford, OR 97501

R. L. Kraus, Hydrologist-in-Charge

Telephone:

(503) $779-2351$

Field Headquarters

Mill Creek Office Park 55513 th St., N.E.

Salem, OR 97310

D. L. Weiss, Hydrologist-in-Charge

Telephone:

(503) $378-3671$ 
